\title{
KARAKTERISTIK HAMBA TUHAN BERDASARKAN 2 TIMOTIUS 2:22-25
}

David Susilo Pranoto

davidsusilopranoto@sttab.ac.id

\begin{abstract}
In this paper the author discusses "Characteristics of God's servants" based on 2 Timothy 2: 22-25. Characteristics are characteristics possessed by someone who distinguishes himself from others in which discuss about character and which leads to good moral values (ethical). This characteristic is also a characteristic that is embedded in the servants of God in their lives interacting with others, to themselves, the surrounding environment and in the ministry. The Apostle Paul in his letter to Timothy so that Timothy as a servant of God does not fall into sin in the face of various temptations of faith that lead to sin, trials, false doctrines, false teachers and various other challenges both inside and outside. Therefore the Apostle Paul advised Timothy to maintain holiness by having the characteristics of God's servants.
\end{abstract}

Keywords: $\quad$ Characteristics, God's Servant.

Abstraksi : Pada tulisan ini penulis membahas tentang "Karakteristik hamba Tuhan" berdasarkan 2 Timotius 2:22-25. Karakteristik adalah ciri khas yang dimiliki oleh seseorang yang membedakan dirinya dengan orang lain yang di dalamnya membahas tentang watak dan yang mengarah pada nilai-nilai moral yang yang baik (etis). Karakteristik ini juga merupakan merupakan ciri khas yang tertanam dalam diri hamba Tuhan dalam kehidupannya berinteraksi dengan orang lain, kepada diri sendiri, lingkungan sekitar maupun dalam pelayanan. Rasul Paulus dalam suratnya kepada Timotius supaya Timotius sebagai hamba Tuhan tidak jatuh ke dalam dosa dalam menghadapi berbagai godaan iman yang membawa ke dalam dosa, cobaan, doktrin palsu, guru-guru palsu dan berbagai tantangan lainnya baik itu dalam diri sendiri maupun dari luar. Oleh sebab itu Rasul Paulus menasihati Timotius untuk tetap menjaga kekudusan dengan memiliki karakteristik hamba Tuhan.

Kata Kunci: Karakteristik, Hamba Tuhan.

\section{LATAR BELAKANG}

Karakteristik adalah bagian dari etika. Etika adalah ilmu tentang nilai-nilai yang menyangkut tentang yang benar, yang baik dan yang tepat. Etika hanya ingin melihat manusia dari sisi baiknya saja. Jadi etika dapat dijadikan cermin untuk dapat melihat keburukan atau kejahatan ${ }^{1}$. Kata Karakter dalam Kamus Besar Bahasa Indonesia sifat khas yang dimiliki oleh individu yang membedakannya dari individu lain; watak; sifat; tabiat; bakat. Karakteristik artinya memiliki sifat khas sesuai dengan perwatakan tertentu;

${ }^{1}$ Edi D. H Siahaan, R. Tambunan, Manginar Manik Etika Sekolah Menengah Teologi Kristen, (Medan: Mitra Medan, 2006), 11 
memiliki kekhususan/kekhasan tersendiri; khas². Artinya bahwa karakteristik merupakan ciri khas yang dimiliki oleh seseorang yang tidak sama dengan orang lain.

Karakteristik yang positif akan menentukan manusia sukses. Lebih dari itu, hidup baik adalah perintah Tuhan. Menurut pandangan dan iman kristiani, manusia secara jasmani (tubuh), mental (jiwa), dan rohani (roh) harus suci sebagaimana Kristus suci, itulah ajaran Kristiani. Dengan itu orang Kristen memikul tanggungjawab yang sangat besar sebagaimana ditegaskan oleh firman Tuhan (Kisah Para Rasul 26:24-25). Karakteristik yang dimiliki oleh Tuhan Yesus selama pelayanan di muka bumi dapat pelajari melalui perkataan, ajaran dan perbuatanNya yang adil. Satu-satunya informasi untuk mempelajari tentang Tuhan Yesus dan kebenaran firmanNya adalah Alkitab ${ }^{3}$. Artinya bahwa karakter Kristus yang sempurna dan sebagai hamba Tuhan harus belajar dari karakter Kristus melalui Firman Tuhan.

Paulus menjelaskan:

Yakni orang-orang yang tidak bercacat, yang mempunyai hanya satu istri yang anak-anaknya hidup beriman dan tidak dapat dituduh karena hidup tidak senonoh atau hidup tidak tertib. Sebab, sebagai pengatur rumah Allah penilik jemaat harus tidak bercacat, tidak angkuh, bukan pemberang, bukan peminum, bukan pemarah, tidak serakah, melainkan suka memberi tumpangan, suka akan yang baik, bijaksana, adil, saleh, dapat menguasai diri dan berpegang kepada perkataan yang benar, yang sesuai dengan ajaran yang sehat, supaya ia sanggup menasihati orang berdasarkan ajaran itu dan sanggup meyakinkan penentang-penentangnya (Titus 1:6-9) ${ }^{4}$.

Jadi, sebagai seorang hamba Tuhan dan pemimpin rohani haruslah memiliki karakteristik seperti Kristus dalam melakukan pelayanan bersama dengan pelayan lainnya dan berelasi dengan mereka dalam bentuk kerja sama yang baik. Dari paparan di atas, memberikan alasan mengapa penulis memilih judul "Karakteristik hamba Tuhan" yaitu supaya hamba Tuhan sebagai pemimpin rohani hidup sesuai dengan firman Tuhan yang penuh dengan kasih (Galatia 5:14-15), supaya hamba Tuhan memiliki karakteristik seorang hamba berdasarkan 2 Timotius 2:22-25 seperti Rasul Paulus dan diajarkan juga kepada Timotius.

\footnotetext{
${ }^{2}$ Siswo Prayitno Hadi Podo, Kamus Besar Bahasa Indonesia..., 413

${ }^{3}$ Ibid., 28

${ }^{4}$ Ibid., 141
} 


\section{KARAKTERISTIK HAMBA TUHAN BERDASARKAN 2 TIMOTIUS 2:22-25}

Surat 2 Timotius ini ditulis oleh Paulus sendiri yang berisikan nasihat-nasihat pribadi Paulus kepada Timotius sebagai teman sekerja dan pembantu yang masih muda ${ }^{5}$. Inti nasihatnya adalah supaya Timotius tabah. Ia dinasihati dan didorong supaya terus setia menyebarkan berita Tuhan Yesus serta berpegang pada ajaran Tuhan Yesus.

Stampas menjelaskan dalam bukunya bahwa: "ketika Paulus mengirim surat yang kedua ini, Timotius masih berada di Efesus ${ }^{6}$. Paulus digambarkan sedang berada dalam penjara ketika menulis surat kepada Timotius ini (2 Timotius 1:8, 16-17). Paulus akan segera menghadapi hukuman mati (2 Timotius 4:6). Bagi Paulus, Timotius seperti anaknya sendiri (1 Timotius 1:2) karena mereka telah mengadakan perjalanan bersama dan bekerjasama dengan erat (Roma 16:21; 1 Korintus16:10; Filipi 2:19; Kisah Para Rasul 16:13) ${ }^{7}$. Klemens dalam bukunya mengatakan di dalam suratnya bahwa “... Paulus mengajarkan kebenaran kepada seluruh dunia, dan ketika ia telah mencapai batas wilayah Barat ia memberikan kesaksiannya kepada para penguasa..." 8 . Paulus mengajarkan tentang Injil karena pada saat itu banyak injil yang berisikan dongeng. Drane mengatakan dalam bukunya bahwa:

Banyak surat Paulus ditulis sebagai tanggapan terhadap ancaman-ancaman yang datang dari berbagai lawan: para pengajar keKristenan yang bercorak Yahudi di Galatia, para asketik di Kolose dan para Gnostik Yahudi di Korintus. Timotius dan Titus menghadapi masalah-masalah yang sama, dan sedang di bawah tekanan supaya meninggalkan berita Injil seperti yang disampaikan Paulus kepada mereka. Paulus menulis suratnya kepada Timotius karena pada saat itu ada banyak ancaman dan ajaran Palsu yang menentang Injil Kristus yang disampaikan oleh Timotius ${ }^{9}$.

Chauke dan Beckelhymer dalam bukunya bahwa "Rasul Paulus menulis surat ini kepada Timotius. Tujuannya ialah untuk menolong Timotius menghadapi kesulitankesulitan sebagai pemimpin Kristen ${ }^{10}$. Rasul Paulus sendirilah yang menulis surat Timotius ini guna untuk menolong Timotius dalam berbagai tantangan yang akan di hadapi dalam pelayanan.

\footnotetext{
${ }^{5}$ Arnold E. Airhart. "Beacon Bible Commentary", Vol. IX. (USA: Beacon Hill Press, 1969). 433 438.

${ }^{6}$ M.H. Cressey, Timotius Dan Titus Dan Donald Guthrie C. Stamps, Alkitab Penuntun Hidup Berkelimpahan (Malang: Gandum Mas, 2006), 2031

${ }^{7}$ Howard Clark Kee, Alkitab Edisi Studi, (LAI, 2011), 1961

${ }^{8}$ I Klemens, The Apostolic Fathers (London: William Heinemann, 1919) 1,7

${ }^{9}$ Jhon Drane, Memahami Perjanjian Baru..., 394

${ }^{10}$ E. Chauke Dan B. Beckelhymer, Penyelidikan Perjanjian Baru Jilid 3 (Bandung: Kalam Hidup, ),
} 


\section{Kajian Eksegetis Teologi 2 Timotius 2:24-25}

Pada bagian ini akan memaparkan tentang studi eksegesis untuk menjelaskan bagaimana pentingnya "Karakteristik hamba Tuhan".

\section{"Menjauhi Nafsu Orang Muda" (ayat 22)}

Kata Jauhilah dalam bahasa Yunani menggunakan kata $\phi \epsilon \hat{\gamma \epsilon}\left(\right.$ pheugo ${ }^{11}$, artinya lari, melarikan diri, menjauhi, hilang ${ }^{12}$. Dengan kasus verb imperative present active 2 nd person singular. Kata kerja yang menyatakan perintah yang ditunjukkan kepada orang ke2 tunggal. Kata $\phi \epsilon \hat{\gamma} \epsilon$ (pheugo) berasal dari kata $\phi \epsilon u ́ \gamma \hat{~}$ (pheugo) ${ }^{13}$, yang artinya seek safety in flight, disappear (mencari keselamatan, melarikan diri, menghilang lenyap). Dalam TL memakai kata larikanlah. Kamus Besar Bahasa Indonesia jauhilah memiliki arti pergi menghindari supaya jauh, meninggalkan ${ }^{14}$. Arichea dan Hatton dalam bukunya mengatakan bahwa "kata Jauhilah juga dapat diterjemahkan menjadi "Hindarilah" 15. Charles F. Pfeiffer dan Everett F. Harrison mengatakan bahwa “...Jauhilah merupakan panggilan untuk memisahkan diri dari kumpulan orang jahat; atau dapat juga disebut sebagai panggilan untuk bersekutu dengan umat Allah dan mencari berbagai anugerah roh"16. Artinya hamba Tuhan harus memisahkan diri dari perkumpulan orang jahat dan mendekatkan diri kepada Tuhan.

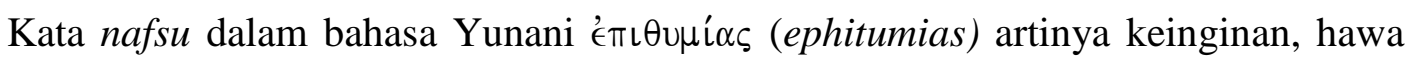
nafsu, hasrat ${ }^{17}$, dengan kasus noun accusative feminine plural common menujukan kata benda yang menyatakan maksud (penderitaan) kepada orang banyak. Barclay mengatakan bahwa: "Nafsu yang dimaksud bukan hanya nafsu kedagingan melainkan termasuk di dalamnya ketidak sabaran, penonjolan diri, menyukai pertengkaran, menyukai sesuatu yang baru" ${ }^{18}$. Artinya bahwa nafsu yang dimaksud ada banyak pengertian, baik itu berbicara tentang seks, ketamakan, cinta akan uang dan keserakahan akan sesuatu hal.

\footnotetext{
${ }^{11}$ Sabda

${ }^{12}$ Hasan Susanto, Perjanjian Baru Interlinear Yunani-Indonesia dan Konkordansi Alkitab Perjanjian Baru (PBIK) Jilid II (Jakarta: LAI, 2006), 790

${ }^{13}$ Bibleworks7, Word Analysis, Bmg Morphology Dan Gingrich

${ }^{14}$ Dendy Sugono, Kamus Besar Bahasa Indonesia, (Jakarta: PT. Gramedia Pustidaka Utama, 2011), 571

${ }^{15}$ Daniel C. Arichea Dan Howard A. Hatton, Surat-Surat Paulus Kepada Timotius dan Kepada Titus, (Jakarta: Lai, 2014), 212

${ }^{16}$ Charles F. Pfeiffer dan Everett F. Harrison, The Wycliffe Bible Commentari Volume 3, (Malang: Gandum Mas, 2013), 892

17 Hasan Susanto, Perjanjian Baru Interlinear Yunani-Indonesia dan Konkordansi Alkitab Perjanjian Baru (PBIK) Jilid II..., 301

${ }^{18}$ William Barcalay, Pemahaman Alkitab Setiap hari..., 279
} 
Orang muda dalam bahasa Yunani $v \epsilon \omega \tau \epsilon \rho \iota \grave{\alpha}_{\text {s }}$ (neoterikos) ${ }^{19}$ dengan kasus Adjective normal accusative feminine plural no degree menunjukkan kata sifat yang ditujukan kepada semua orang tanpa terkecuali. ${ }^{20}$

Dari frasa "jauhilah nafsu orang muda" adalah perintah keras yang Paulus perintahkan kepada Timotius sebagai hamba Tuhan supaya selalu membatasi diri dan menyelamatkan diri dari berbagai-bagai kesenangan orang muda yang menyebabkan fikiran jahat yang sering timbul. Menjauhkan diri dari nafsu orang muda merupakan hal yang paling sukar untuk dilakukan oleh siapapun, sebab nafsu orang muda ini merupakan nafsu yang memiliki hasrat yang sangat tinggi yang ingin selalu dipenuhi. Sifat yang seperti itu terdapat di dalam diri setiap manusia. Oleh sebab itu, Timotius harus bisa mengendalikan setiap keinginan daging yang tinggi yang ada dalam dirinya di saat berhadapan dengan berbagai ancaman dan godaan yang membuat dirinya lupa akan Tuhan. "Mengejar Keadilan" (Ayat 22)

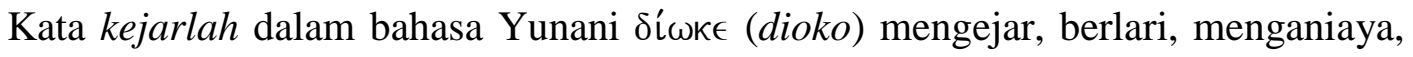
mengusir, mencari ${ }^{21}$, dengan kasus verb imperative present active 2 nd person singular (kata kerja yang menyatakan bahwa mengejar keadilan adalah suatu keharusan yang harus dimiliki oleh orang kedua tunggal). Versi KJV memakai kata follow after yang berarti setelah mengikuti ${ }^{22}$. TL memakai kata tuntutlah. Kata kejarlah juga merupakan istilah yang lebih kuat dari pada usahakanlah ${ }^{23}$. Usaha adalah kegiatan untuk mengarahkan tenaga, fikiran untuk mencapai sesuatu maksud.

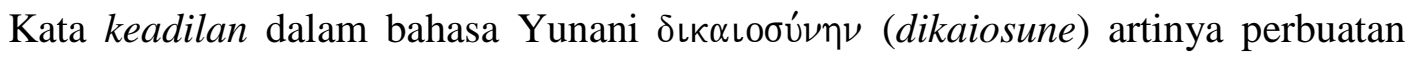
benar, keadilan, ketentuan Allah, pembenaran, status atau hubungan yang benar, kewajiban agama, pendermaan, kehendakNya, kebenaranNya ${ }^{24}$, dengan kasus noun accusative feminine singular kata ini menunjukan kata benda yang menunjukkan sifat yang lembut ditunjukkan kepada orang pertama tunggal. Secara harafiahnya bahwa Timotius dituntut untuk mengejar kebenaran dan keadilan yang menjadi keharusan bagi Timotius sebagai hamba Tuhan.

\footnotetext{
${ }^{19}$ Sabda

${ }^{20}$ Hasan Susanto, Perjanjian Baru Interlinear Yunani-Indonesia dan Konkordansi Alkitab PB (PBIK) Jilid II...,

${ }^{21}$ Hasan Susanto, Perjanjian Baru Interlinear Yunani-Indonesia dan Konkordansi Alkitab Perjanjian Baru (PBIK) Jilid II..., 218

${ }^{22}$ Spiros Zodhiates, The Hebrew-Greek Lexicon Revised..., 1405

${ }^{23}$ Lewis Jhonson, "1 Korintus" dalam Charles Pfeiffer dan Everett F. Horrison (Ed), The Wiclife Bible Comentary, (Malang: Gandum Mas, 2001), 608

24 Hasan Susanto, Perjanjian Baru Interlinear Yunani-Indonesia dan Konkordansi Alkitab Perjanjian Baru (PBIK) Jilid II..., 213
} 


\section{"Kesetiaan" (Ayat 22)}

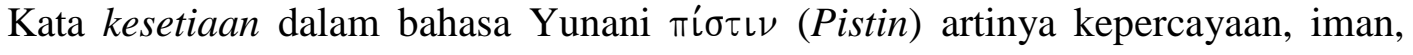
kesetiaan, agama, ajaran yang diimani, janji, bukti ${ }^{25}$, dengan kasus noun accusative feminine singular. Kata benda yang menunjuk kepada subjek yang artinya "kesetiaan

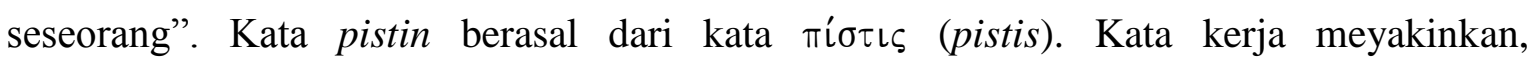
mempercayai, mentaati, menaruh keyakinan, percaya, yakin ${ }^{26}$. Secara harafiah bahwa Timotius harus menunjukkan kesetiaannya dan keyakinannya akan Tuhan, baik dalam iman, maupun dalam menjalin sebuah relationship terhadap sahabat, dalam pelayanan, kepada tuan dan dalam kehambaan.

\section{“Hidup Dalam Kasih" (Ayat22)}

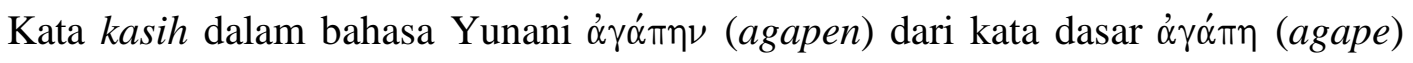
yang artinya kasih, perjamuan $\mathrm{kasih}^{27}$, dalam kasus noun accusative feminine singular. Kata benda yang tertuju kepada orang pertama tunggal seperti sifat perempuan pada umumnya. Sedangkan singular adalah kata yang menunjuk kepada objek. Dalam KJV memakai kata charity yang artinya kemurahan hati tanpa balas ${ }^{28}$. Dalam Perjanjian Baru, kata yang paling umum digunakan untuk kata kasih adalah agape. Palmer menjelaskan bahwa "kasih berarti yang paling tinggi dan yang paling mulia, terjemahan ini cenderung diambil dari LXX yang menggambarkan kasih Allah kepada manusia dan kasih manusia kepada sesamanya ${ }^{29}$. Artinya bahwa kasih lebih tinggi dari pada karakter lainnya yang berhubungan dengan Allah dan sesama.

Moulton menggunakan kata "agape yaitu Love kindly concern, devotedness" 30 artinya kasih, baik/ramah, peduli, sangat setia, sangat penyayang ${ }^{31}$. Zodhiates mengartikan kata ini secara harafiah berarti "To love, affectionate, good will, benevolence" ${ }^{32}$, artinya untuk cinta, kehendak baik, kebajikan. Dalam Kamus Besar Bahasa Indonesia kata kasih artinya beri; memberi, perasaan sayang, $\operatorname{cinta}^{33}$.

\footnotetext{
${ }^{25}$ Hasan Susanto, Perjanjian Baru Interlinear Yunani-Indonesia dan Konkordansi Alkitab Perjanjian Baru (PBIK) Jilid II..., 641

${ }^{26}$ William B. Eerdmans, Exegetical Dictionary of the New Testament, (America: Publishing Company, 1999), 63

${ }^{27}$ Hasan Susanto, Perjanjian Baru Interlinear Yunani-Indonesia dan Konkordansi Alkitab Perjanjian Baru (PBIK) Jilid II...,6

${ }^{28}$ Ibid., 934 2002), 525

${ }^{29}$ Palmer, “Kasih” dalam JD. Douglas (Ed), Ensiklopedi Alkitab Masa Kini Jilid I (Jakarta: YKBK,

${ }^{30}$ Harolk K. Moulton, The Analitical Greek Lexicon revised, (American:Zondervan Publishing House, 1977), 2

${ }^{31}$ John M. Echlos, Kamus Inggris Indonesia, (Jakarta: Gramedia Pustidaka Utama, 1982), 135-188

${ }^{32}$ Spiros Zodhiates, Wordstudy Dictionary New Testament, (U.S.A: AMG, 1993), 66

${ }^{33}$ Siswo Prayitno Hadi Podo, Kamus Besar Bahasa Indonesia..., 421
} 


\section{Barclay mengatakan:}

mengasihi orang lain adalah memandang mereka seperti Allah memandang mereka. Ia tidak melakukan apapun kecuali mencari hal terbaik bagi mereka. Itu berarti membalas kebencian dengan pengampunan, membalas dendam dengan kasih, membalas sikap acuh tidak acuh dengan perhatian menyala yang tidak dapat dipadamkan ${ }^{34}$.

Artinya bahwa kasih yang dimiliki adalah kasih yang tidak pernah memandang status seperti Allah dan tidak membalas kejahatan.

Browning dalam bukunya mengatakan:

Dalam surat-surat Rasul Paulus kasih dengan iman dan pengharapan (1 Korintus 13:13) sebagai karunia Roh Kudus. Kasih itu bukan kasih usaha manusia dan oleh karena itu bukan alasan untuk membanggakan diri (1 Korintus 13:4), pengorbanan Kristus di kayu salib adalah tanda tertinggi dari kasih Allah (Roma 8:39). Oleh karena itu gaya hidup orang Kristen harus berteladan kepadaNya ${ }^{35}$.

Artinya bahwa kasih yang dimiliki oleh manusia berasal dari Allah melalui kematianNya di atas kayu salib.

Brill mengatakan "kasih seperti kasih terhadap saudara sendiri adalah dasar dan kegenapan kehidupan Kristen. Kasih juga menjadi dasar segala hubungan sosial. Jikalau seseorang mempunyai kasih sedemikian, tentu ia akan berusaha supaya ia tidak menjadi beban bagi orang lain $^{36}$. Artinya bahwa manusia yang memiliki kasih bisa menempatkan diri dimanapun berada dan bisa menjalin relationship dengan semua orang serta tidak menjadi beban bagi orang lain. Barclay juga mendukung pernyataan Brill bahwa Kasih adalah kasih persaudaraan, kasih kepada persekutuan umat Kristus yang kepadanya Timotius diutus. Sifat kasih yang seperti inilah yang memberikan kualitas kepada seorang hamba Tuhan, ia harus mengasihi orang lain sedemikian rupa sehingga tidak perlu ada kesulitan yang terlalu berat untuk diatasi demi mereka atau tidak ada situasi mengancam yang membuatnya patah semangat. Tidak seorangpun hamba Tuhan bisa melayani dengan baik tanpa ada kasih di dalam hatinya ${ }^{37}$. Artinya bahwa kasih yang tertanam dalam diri akan menunjukkan kualitas hidup sebagai hamba Tuhan, sebab dalam pelayanan yang dibutuhkan adalah kasih. Jadi penulis menarik sebuah kesimpulannya bahwa Timotius dalam pelayanannya harus memiliki kasih sebagai penunjuk kualitas diri yang mengasihi

\footnotetext{
${ }^{34}$ William Barclay, Pemahaman Alkitab Setiap hari..., 240-241

${ }^{35}$ Browing, Kamus Alkitab, (Jakarta: Gunung Mulia, 2011), 175

${ }^{36}$ J. Wesley Brill, Tafsiran Surat Tesalonika, (Bandung: Yayasan Kalam Hidup, 2008), 66

${ }^{37}$ William Barclay, Pemahaman Alkitab Setiap Hari..., 225
} 
Allah dan manusia tanpa memandang status, serta bisa menempatkan diri dan membawa dampak yang baik dimanapun berada.

\section{“Tidak Boleh Bertengkar" (Ayat 24)}

Kata Tidak dalam bahasa Yunani oủ (ou) artinya tidak, bukan, jahat ${ }^{38}$, particle or disjunctif part other. Kata boleh dalam bahasa Yunani $\delta \in \hat{\imath}$ (dei) dalam bentuk verb indicative present active $3 r$ person singular ${ }^{39}$, yang artinya mengharuskan, perlu, seharusnya. Kata bertengkar dalam bahasa Yunani $\mu \alpha \dot{\chi} \chi \sigma \theta \alpha \iota$ machomai artinya bertengkar, berkelahi ${ }^{40}$, verb infinitive present middle. Kata bertengkar berupa kata kerja dari "pertengkaran" pada ayat sebelumnya dan digunakan dalam arti yang jelek ${ }^{41}$. Kata tidak bertengkar dalam bahasa inggris not quarrelsome (tdk suka bertengkar) ${ }^{42}$. Dalam BIS orang yang bekerja buat Tuhan tidak patut bertengkar. Dalam FAYH memakai kata umat Allah hendaknya jangan suka bertengkar. "Bukan pemarah" dalam bahasa Yunani $\mu \eta \pi \lambda \eta \dot{\kappa} \tau \eta \varsigma$ (me plektes), yang berarti bukan pemarah, kasar atau suka bertengkar. Kata $\pi \lambda \eta ́ k \tau \eta \varsigma$ (plektes) adalah kata benda yang menggambarkan sifat orang yang cepat marah dan yang tidak ragu-ragu menggunakan kekerasan terhadap orang yang mengganggunya atau orang kontroversial, petarung. Jadi $\mu \eta^{\prime} \pi \lambda \eta \dot{\kappa} \tau \eta \varsigma$ (me plektes) artinya orang yang bukan pemarah melainkan peramah, sabar atau cermat dan tidak suka bertengkar $^{43}$. Secara harafiah sebagai umat Allah dan pekerja Kristus jangan yang suka bertengar, kasar dan cepat marah.

Henry mengatakan bahwa "Hamba Tuhan yang cenderung suka bertengkar tidak cakap mengajar, mereka garang dan tidak taat. Tetapi hamba Tuhan harus sabar dalam menghadapi kejahatan dan dapat menuntun orang yang tunduk maupun yang suka melawan" ${ }^{44}$. Artinya bahwa hamba Tuhan yang suka bertengkar tidak bisa menegur kesalahan orang lain. Houston dalam bukunya mendukung pernyataan Henry bahwa: "cara hidup seorang hamba Tuhan harus mencerminkan kebenaran yang diperkatakan. Seorang hamba Tuhan tidak boleh bertengkar atau berkelahi, melainkan harus berpegang

${ }^{38}$ Hasan Susanto, Perjanjian Baru Interlinear Yunani-Indonesia dan Konkordansi Alkitab Perjanjian Baru (PBIK) Jilid II..., 585

${ }^{39}$ Ibid., 184

${ }^{40}$ Ibid., 506

${ }^{41}$ Charles F. Pfeiffer dan Everett F. Harrison, The Wycliffe Bible Commentari Volume 3 ..., 1163

${ }^{42}$ Andreas Halim, Kamus Lengkap 50 Miliyar, (Surabaya: Sulita Jaya), 267

${ }^{43}$ A.M. Stibbs, Tafsiran Alkitab Masa Kini, Pen., A. Lumbatobing Jilid 3, (Jakarta: Yayasan Komunikasi Bina Kasih, 2013), 693

${ }^{44}$ Matthew Henry, Surat Galatian, Efesus, Filipi, Kolose, 1 dan 2 Tesalonika, 1 dan 2 Timotius, Titus dan Filemon..., 686 
pada kebenaran dengan lemah-lembut dan penuh kasih"45. Artinya bahwa seorang hamba Tuhan harus berpegang pada setiap ajaran yang disampaikannya (integritas). Jadi penulis menarik sebuah kesimpulan bahwa sebagai umat Tuhan dan Timotius sebagai pelayan Tuhan dilarang keras untuk bertengkar. Sebab pertengkaran tidak mengerjakan apa yang baik dan tidak bisa menegur kesalahan orang lain.

\section{"Ramah Terhadap Orang lain" (Ayat 24)}

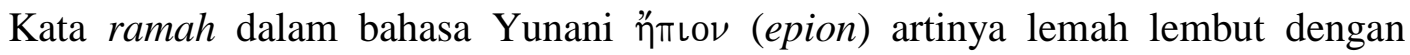
kasus adjective normal accusative masculine singular no degree ${ }^{46}$. Kata sifat yang menunjukkan sebuah perintah keras kepada semua orang. Dalam ENDE memakai kata baik hati. Dalam versi TL memakai kata manis. Kata Orang lain dalam bahasa Yunani $\pi \alpha ́ \nu \tau \alpha \varsigma$ (pantas) artinya semua, seluruh, setiap, apa saja, siapa saja, segala, segala dapat, berarti sangat ${ }^{47}$, dengan kasus adjective indefinite accusative masculine plural no degree. Kata sifat yang ditunjukkan kepada semua orang tanpa terkecuali. Dalam versi NKJV memakai kata to all artinya semua orang. sedangkan arti semua orang dalam Kamus Besar Bahasa Indonesia artinya sekalian, segala, semuanya, sekalian, segenap, segala-galanya ${ }^{48}$. Secara harafiah bahwa Timotius harus menunjukkan karakter ramah yang berasal dari hati dan menunjukkannya dengan manis kepada semua orang.

\section{“Cakap Mengajar" (Ayat 24)}

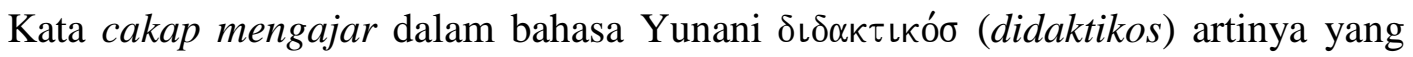
pandai mengajar ${ }^{49}$, dengan kasus adjective normal accusative masculine singular no degree. Ini menunjukkan suatu kata sifat yang ditunjukan kepada objek berarti mampu mengajar, pandai mengajar atau memiliki kemampuan, kemahiran dan kepandaian dalam pengajaran. KJV memakai kata "apt to teach",50. Apt artinya tangkas, cerdas dan teach artinya mengajar, mengajarkan, menghajar ${ }^{51}$. FAYH memakai kata sabar mengajar orangorang yang salah. ENDE memakai kata sabar dalam segala kesukaran. BIS mengajar orang dengan baik. Secara harafiah artinya bahwa Timotius harus pandain mengajar orang-orang yang berbuat salah dengan baik dan penuh kesabaran baik itu dalam keadaan sukar maupun suka.

\footnotetext{
45 James Houston, Handbook to the Bible, (IKAPI, 2002), 703

${ }^{46}$ Charles F. Pfeiffer dan Everett F. Harrison, The Wycliffe Bible Commentari Volume 3..., 351

${ }^{47}$ Ibid., 616

${ }^{48}$ Siswo Prayitno Hadi Podo, Kamus Besar Bahasa Indonesia..., 778

${ }^{49}$ Ibid., 203

${ }^{50}$ Strong's Numbers dalam Bilble Works 7

${ }^{51}$ Jhon M, Echols, Kamus Inggris Indonesia, (Jakarta), 580
} 
Barclay mengatakan bahwa "mungkin diantara hamba Tuhan ada yang memiliki karunia mengajar dan ada pula yang tidak memiliki untuk mengajar atau menjelaskan imannya. Namun sekalipun tidak memiliki karunia untuk mengajar, ia mampu bersaksi mengenai kuasa Injil yang hidup",52. Artinya bahwa mengajar memang tidak diharuskan karena tidak semua hamba Tuhan memiliki karunia mengajar. Namun hamba Tuhan harus bisa menyaksikan Injil Kristus melalui kesaksian hidupnya. Guthrie mengatakan:

Paulus memfokuskan perhatiaannya kepada orang-orang yang memegang jabatan harus menunjukkan teladan yang baik bagi orang lain. Mereka harus pandai mengajar, karena peranan mereka adalah untuk meneruskan apa yang telah diajarkan kepada mereka sendiri (2 Tim. 2:2)"53.

Artinya bahwa setiap orang yang menjadi pekerja Kristus harus bisa mengajarkan Injil Kristus kembali kepada semua orang dan bisa mempertangungjawabkannya. Barclay menekankan kembali:

Para pengajar haruslah orang yang dapat dipercaya. Kata Yunani untuk dapat dipercaya pistos. Orang yang pistos adalah orang yang percaya, setia dan dapat diandalkan. Hati pengajar hamba Tuhan hendaklah tetap tinggal di dalam Kristus sehingga tidak ada ancaman atau bahaya yang akan memikat dirinya dari jalan kesetiaan dan tidak ada bujukan ajaran sesat yang akan menyesatkan dari jalan kebenaran. Ia harus teguh baik dalam hidup maupun dalam fikirannya ${ }^{54}$.

Artinya bahwa Timotius sebagai pengajar harus dapat dipercaya, diandalkan serta setia dalam dalam Injil Kristus.

Dari pembahasan di atas maka penulis menarik sebuah kesimpulan bahwa Paulus mempercayakan tugas mengajar ini kepada para pemimpin jemaat yaitu Timotius sebagai hamba Tuhan harus bisa mengajarkan Injil Kristus kepada orang Kristen maupun nonKristen, harus bisa menyatakan dan membuktikan berbagai kesalahan ajaran sesat dan menjadi pengajar yang bisa dipercaya (2 Timotius 2:24, 1 Timotius 5:17).

\section{"Sabar" (Ayat 24)}

Kata kesabaran dalam bahasa Yunani $\mu \alpha \kappa \rho о \tau \eta u \mu\llcorner\alpha ~(m a k r o t h u m i a)$ (ditunjukkan terhadap orang lain) yang memiliki arti to be slow towards, be long enduring, to exersice patience, be long suffering, wait with patient expectation ${ }^{55}$, artinya menjadi lambat, tahan lama, melatih kesabaran, menderita lama, menunggu dengan harapan pasien. Kata

\footnotetext{
${ }^{52}$ William Barclay, Pemahaman Alkitab Setia Hari..., 246

${ }^{53}$ Donald Guthrie, Teologi Perjanjian Baru, (Jakarta: BPK Gunung Mulia, 1996), 92

${ }^{54}$ William Barclay, Pemahaman Alkitab Setia Hari..., 247. Falconer berkata bahwa "orang-orang percaya itu demikian "bahwa mereka tidak melakukan penganiayaan ataupun kesalahan"

${ }^{55}$ Harold K. Moulton, The Analitical Greek Lexicon Revised..., 256
} 
kesabaran berasal dari kata sabar dalam bahasa Yunani $\alpha \nu \in \xi ं \kappa \alpha \kappa o \nu ~(a n e x i k a k o s)$ artinya yang menanggung perlakuan jahat tanpa kebencian berarti sabar ${ }^{56}$, dalam bentuk adjective accusative masculine singular no degree. Kata sifat yang dimiliki tanpa batas. kata sabar dalam Kamus Besar Bahasa Indonesia artinya tahan menghadapi cobaan (tidak lekas marah, tidak lekas putus asa, tidak lekas patah hati), tabah, tenang, tidak tergesa-gesa, tidak terburu nafsu. Secara harafiahnya bahwa Timotius harus memiliki karakter sabar dan tahan terhadap apapun cobaan dan penderitaan yang dihadapi dan tidak cepat putus asa serta cepat marah.

Kesimpulannya bahwa Timotius dalam menghadapi berbagai godaan, Timotius harus memiliki kesabaran yang tanpa batas yang tidak cepat marah dan tidak pernah menaruh kebencian terhadap orang yang membuat sakit hati.

\section{"Lemah Lembut" (Ayat 25)}

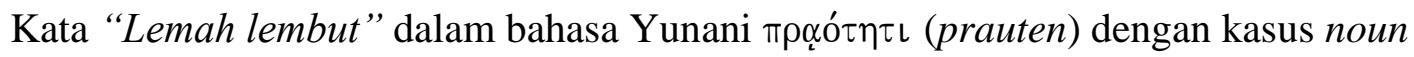
dative feminine singular ${ }^{57}$, yang artinya kelemah lembutan, rendah hati. Kata yang menujuk kepada subjek yang artinya seseorang yang memiliki sifat yang lemah-lembut. Henry dalam bukunya menegaskan bahwa;

kelemah-lembutan juga dilakukan terhadap orang-orang yang telah membangkitkan kemarahan, atau dengan cara apapun menyakiti. tidak boleh terseret dalam kemarahan karena tidak pantas marah, dihina dan diabaikan, tetapi justru harus bijaksana membungkam marah sendiri dan sabar menanggung amarah orang lain ${ }^{58}$.

Artinya hamba Tuhan harus bisa mengontrol amarah dan menguasai diri jika berhadapan dengan orang-orang yang suka membangkitkan amarah serta bisa berlaku sabar. Brien memberikan pendapat yang sama bahwa "orang yang lemah lembut adalah orang yang penuh pertimbangan untuk orang lain dan kemauan untuk membebaskan orang lain" 59. Dunn juga menegaskan bahwa "kelemah-lembutan adalah kekuatan yang memungkinkan bisa bertemu dengan orang yang sedang konflik dengan orang lain"60. Rasul Paulus mencantumkan kelemah-lembutan dalam uraiannya tentang "buah roh", yang terdapat di Galatia 5:22, 23. Kata Yunani yang diterjemahkan "kelemah-lembutan" di ayat

\footnotetext{
${ }^{56}$ R. Budiman Surat-surat Pastoral I dan II Timotius dan Titus.., 71

${ }^{57}$ Piero Ferrucci, Bagaimana Menjadi Orang Baik, (Jakarta: Gunung Mulia, 2009), 667

${ }^{58}$ Matthew Henry, Surat Galatia, Efesus, Filipi, Kolose, Idan 2 Tesalonika, 1 dan 2 Timotius, Titus, Filemon, (Surabaya: Momentum, 2015), 398-399 1982), 199

${ }^{59}$ Peter T. O’Brien, Word Biblical Commentary Volume 44 Collosians, Philemon, (Texas: Waco,

${ }^{60}$ James D. G. Dunn, The Epistles To The Colossians and To Philemon A Commentary On The Greek Text, (Grand Rapids, Michigan, 1996), 228
} 
23 dalam Terjemahan Dunia Baru sering kali diterjemahkan "kelembutan hati" atau "kelembutan" dalam terjemahan-terjemahan Alkitab lainnya. Sebenarnya, sulit untuk menemukan kata yang persis sepadan dengan kata Yunani ini dalam kebanyakan bahasa lainnya, karena ungkapan aslinya menggambarkan, bukan sifat lembut, sopan, dan penuh kesabaran yang tampak dari luar, melainkan sifat lemah lembut dan penuh timbang rasa di dalam diri seseorang; bukan cara seseorang berperilaku, melainkan kondisi fikiran dan hatinya. Kelemah-lembutan berkaitan erat dengan 'kerendahan hati'. Sebaliknya, keangkuhan membuat seseorang suka meninggikan diri dan bisa jadi sering memperlakukan orang lain secara kasar dan tidak berperasaan ${ }^{61}$.

Kesimpulannya ialah bahwa kelemah-lembutan tidak hanya tertuju pada sifat yang sopan yang tampak diluar diri melainkan lemah-lembut mencakup kerendahan hati yang terpancar dari dalam hati.

\section{$\underline{\text { Kajian Teologis }}$}

Pada bagian ini penulis akan membahas beberapa kajian teologis tentang "karakteristik seorang hamba Tuhan terhadap orang lain" berdasarkan 2 Timotius 2:22-25 sesuai dengan kajian eksegetis di atas.

\section{"Menjauhi Nafsu Orang Muda"}

Menjauhi nafsu orang muda merupakan kehendak Tuhan dalam kehidupan setiap orang percaya dan terlebih dalam kehidupan hamba Tuhan. Untuk menjauhi nafsu orang muda harus menjaganya sesuai dengan Firman Tuhan (Mazmur 109:1). Nafsu orang muda yang dimaksud ialah nafsu yang bertentangan dengan firman Tuhan dan dengan buah Roh Kudus karena nafsu orang muda selalu berujung pada sifat dosa dan kebodohan menurut Alkitab. Macam-macam nafsu orang muda ialah percabulan, kenajisan, hawa nafsu, keserakahan yang sama dengan penyembah berhala (Kolose 3:5) dan cinta akan uang (1 Timotius 6:10).

Dalam pembahasa menjauhi nafsu orang muda ini, Usman dan Ishak memberikan pengertian tentang apa itu hawa nafsu. Hawa nafsu terdiri dari dua kata yaitu hawa artinya keinginan, kecenderungan atau keinginan hati yang kuat, sangat cinta, kehendak. Sedangkan nafsu artinya roh nyawa, jiwa, tubuh, kehendak, niat, selera dan usaha. Jadi hawa nafsu artinya dorongan hati yang kuat untuk melakukan perkara yang tidak baik $^{62}$. Artinya bahwa hawa nafsu merupakan sebuah keinginan yang ada dalam tubuh

\footnotetext{
${ }^{61}$ Ibid

${ }^{62}$ Syafrein Effendi Usman dan Norain Ishak, Nafsu dan Perkahwinan, (Kuala Lumpur: Kintan, 1992), 1
} 
manusia dan keinginan yang sangat kuat untuk memenuhi nafsu tersebut sehingga menimbulkan karakter yang tidak baik.

Definisi nafsu menurut Alkitab ialah hasrat atau keinginan seksual yang tidak menghormati dan menolak Allah serta Roh Kudus dalam kehidupannya (1 Tesalonika 4:18). "Menjauhi nafsu orang muda", hal ini juga didukung oleh Budiman dalam bukunya bahwa; "Sebab itu jauhilah nafsu orang muda artinya janganlah Timotius dikuasai hawa nafsu orang muda, yang berwujud tidak dapat mengendalikan diri, lekas naik pitam, terlalu cepat memberikan reaksi. Sifat-sifat seperti ini mudah timbul bila Timotius berhadapan dengan lawan-lawannya" 63 . Artinya bahwa hamba Tuhan harus bisa menjauhi dan meninggalkan nafsu orang muda. Sebab nafsu orang muda sangat sukar untuk dikendalikan oleh siapapun.

Jadi dari kajian menjauhi nafsu orang muda penulis menarik kesimpulan bahwa sebagai hamba Tuhan harus memiliki karakter yang mampu menjauhkan dan meninggalkan nafsu orang muda. Nafsu yang sangat sukar untuk dikendalikan, yang tidak sesuai dengan kehendak Tuhan, yang menolak Tuhan serta menolak Roh Kudus dan akhirnya berujung pada dosa.

\section{"Mengejar Keadilan"}

Seorang hamba Tuhan harus memiliki karakter adil yang tidak memihak ke pada siapa-siapa. Namun bagaimana memiliki karakter adil tersebut yaitu harus dengan latihan untuk selalu berlaku adil terhadap siapapun, meneladani Tuhan Yesus dan belajar dari kebenaran firman Tuhan. Karakter adil sangat diharapkan dalam kehidupan hamba Tuhan, karena jaman sekarang ini keadilan jarang ditemukan, sebab bagi kebanyakan manusia menganggap bahwa keadilan bisa dibeli dengan uang atau sogokan. Jadi dalam hal ini hamba Tuhan diharuskan untuk memiliki karakter adil tersebut, untuk menjadi teladan bagi semua orang.

Kata keadilan berasal dari kata adil, dari bahasa Arab yang berarti "berada di tengah-tengah, jujur lurus dan tulus". Terminology/pengertian kata adil berarti suatu sikap yang bebas dari deskriminasi (perlakuan tidak adil) dan ketidak jujuran. Jadi, orang yang adil adalah orang yang perilakunya sesuai peraturan/hukum, baik hukum agama, hukum positif (hukum Negara), maupun hukum social yang berlaku ${ }^{64}$. Artinya bahwa keadilan/adil yaitu tidak menyimpang ke kanan ataupun ke kiri, melainkan berada di

\footnotetext{
${ }^{63}$ R. Budiman, Surat-surat Pastoral I dan II Timotius dan Titus..., 98

${ }^{64}$ Daniel Ronda, Utuslah Aku, Panggilan Yang Tidak Lekang Oleh Waktu, (Bandung:Yayasan Kalam Hidup, 2012), 234
} 
tengah-tengah dan tidak berat sebelah, memperlakukan orang lain sesuai dengan hukum yang berlaku.

Seorang hamba Tuhan harus memiliki karakter yang mengejar keadilan, ia tidak memihak atau berat sebelah dalam mengambil keputusan ketika terjadi sesuatu hal dan betul-betul berpegang pada kebenaran, sehingga tidak memberikan keputusan sesuka hati. Seorang yang mampu memperlakukan dua pihak atau lebih yang sedang dihadapi dengan tidak berat sebelah tetapi adil. Memperlakukan kedua belah pihak sesuai dengan hak dan tanggung jawab mereka. ${ }^{65}$ Artinya bahwa seorang hamba Tuhan yang suka mengejar keadilan tidak akan bersikap sewenang-wenang dalam mengambil keputusan.

Hamba Tuhan yang berkarakter adil, dalam hidupnya dan kepemimpinannya tidak akan berlaku sewenang-wenang, tidak berat sebelah, melainkan tetap berpegang pada yang benar, karena ia berpegang pada prinsip kebenaran ${ }^{66}$. Artinya bahwa ketika hamba Tuhan/pemimpin berpegang pada prinsip hukum yang berlaku dan kebenaran Tuhan, maka ia tidak akan sewenang-wenang dalam mengambil keputusan dan bahkan tidak memihak serta tidak memandang muka. Melainkan memberlakukan keadilan sesuai jalur kebenaran. Tulus Tu'u mengatakan:

Pemimpin akan dapat hidup, bersikap dan berperilaku adil, kalau ia mengarahkan hidupnya pada Tuhan. Sebab Tuhanlah sumber keadilan baginya. Tuhan Allah adalah hakim yang adil, Tuhan itu adil dalam segala jalan dan perbuatan-Nya. Tuhan adalah Allah yang adil (Mazmur 7:12;145:17; Yesaya.30:18). Dengan hidup yang terarah pada Tuhan, maka keadilan yang dari sorga akan mengisi hati dan fikiran serta hidup pemimpin. ${ }^{67}$

Artinya bahwa hamba Tuhan yang hidupnya berpegang pada kebenaran Tuhan yang sumber keadilan dan kebenaran, maka kehidupannya akan terarah dan karakter adil dari sorga akan dimiliki.

Karakter adil dalam hal-hal yang berkaitan dengan kehidupan sehari-hari, memiliki kebenaran moral dan keadilan dalam menangani persoalan, dengan memberikan kepada semua orang apa yang seharusnya juga merupakan hal yang sangat penting ${ }^{68}$. Ranoh mengatakan bahwa "keadilan juga merupakan prinsip etis" ${ }^{69}$. Artinya bahwa keadilan merupakan nilai moral yang baik.

${ }^{65}$ Chris Marantika, Kepercayaan dan Kehidupan Orang Kristen ...,417

${ }^{66}$ Tulus Tu’u, Pemimpin Kristiani Yang Berhasil, (Bandung:Bina Media Informasi, 2010),50

${ }^{67}$ Ibid.,51

68 Matthew Henry, Tafsiran Galatia, Efesus, Filipi, Kolose, $1 \& 2$ Tesalonika, $1 \& 2$ Timotius,Titus,Filemon...,746

${ }^{69}$ Ayub Ranoh, Kepemimpinan Kharismati, (Jakarta: Gunung Mulia,2011), 192 
Penulis menyimpulkan bahwa seorang hamba Tuhan harus mengejar keadilan dan hidup dalam keadilan serta menjadikan gaya hidup. Supaya menjadi hamba Tuhan yang tidak berat sebelah dan tidak memandang muka serta berlaku sewenang-wenang. Melainkan menjadi hamba Tuhan yang berkarakter mengejar keadilan dan mengarahkan hidupnya dalam kebenaran Tuhan serta meneladani keadilan yang telah Tuhan berikan serta bisa menjadi teladan di manapun berada.

\section{"Kesetiaan"}

Kesetiaan salah satu karakter baik yang ada dalam diri setiap manusia, namun tidak semua manusi bisa setia terhadap sesuatu hal. Kesetiaan hal yang sangat berharga dan penting untuk dijaga guna untuk mencapai tujuan bersama dengan baik. kesetiaan dilakukan terhadap siapapun dan dalam kondisi apapun. Kesetiaan merupakan sebuah komitmen dan pengorbanan. Jika dalam hidup tidak tertanam kesetiaan maka kebahagiaan akan jauh dalam diri (Yakobus 1:8). Kesetiaan bagian dari karakter Allah (Ibrani 13:5; 2 Timotius 2:13).

Dalam hal ini kesetiaan menurut Barclay bahwa: "Hamba Tuhan hendaklah selalu benar dan setia kepada Yesus Kristus. Hamba Tuhan tidak boleh malu menunjukkan siapakah dirinya dan siapa yang dilayaninya. Kesetiaan merupakan kebajikan tertua dan terpenting di dunia"70. Artinya bahwa orang yang memiliki kesetiaan berani menunjukkan identitas dirinya sebagai hamba Tuhan dan pencintraan sebagai hamba Tuhan melalui pengkabaran Inil.

Kesetiaan ialah ketaatan kepada Kristus, ketaatan yang dapat dilakukan, tidak peduli apapun akibatnya. ${ }^{71}$ Kesetiaan juga berbicara tentang iman, seperti yang dikatakan oleh Tulus Tu'u dalam bukunya "iman berarti kesetiaan dan ketaatan kepada Tuhan. Yang artinya Tuhan yang telah menolong dan menyelamatkan dirinya akan ditaatinya. Sehingga manusia akan setia memegang ajaran, pesan, amanat dan janji Tuhan. Kesetiaan dan ketaatan itu mewujud dalam dalam perilaku yang sesuai dengan ajaran, pesan, amanat dan janji Tuhan. sehingga ia menjadi pelaku-pelaku Firman Tuhan, bukan hanya pendengar saja $^{72}$. Artinya bahwa kesetiaan sangat penting bagi kehidupan seorang hamba Tuhan karena kesetiaan, karena kesetian kepada Kristus dan ajaran yang benar merupakan bukti dari iman kepada Kristus. Seorang hamba Tuhan juga tidak hanya memiliki karakter yang

\footnotetext{
${ }^{70}$ William Barclay, Pemahaman Alkitab Setiap Hari..., 240

${ }^{71}$ Ibid., 155

72 Tulus Tu'u, Pemimpin Kristiani Yang Berhasil 2...,46
} 
setia dalam membina relationship terhadap orang lain dan dalam kondisi apapun melainkan juga pada iman dapat diteladani.

Seorang hamba Tuhan perlu mendasari hidupnya pada iman dan kesetiaan kepada Tuhan. Hamba Tuhan perlu secara nyata dilihat dan didengar sebagai pemimpin rohani yang beriman kepada Tuhan. iman yang dimiliki adalah iman yang berbobot, bukan iman yang kosong dan mati. Oleh karena itu iman hamba Tuhan adalah iman akaliah (fikiran, akal) yang dikembangkan menjadi iman hatiah. Sehingga imannya adalah iman yang sungguh-sungguh nampak oleh mata dan kedengaran oleh telinga sesamanya. Yakni terwujud dalam ketaatan dan kesetiaan pada Tuhan. ${ }^{73}$

Dari penjelasan di atas, penulis dapat menyimpulkan bahwa seorang hamba Tuhan harus memiliki karakter yang setia dalam pelayanan, relationship, setia memegang ajaran, pesan, amanat dan janji Tuhan. Kesetiaan dan ketaatan itu mewujud dalam dalam perilaku yang sesuai dengan ajaran sesuai Firman Tuhan, terutama kesetiaan kepada Tuhan.

\section{"Hidup Dalam Kasih"}

Kasih merupakan bagian buah Roh Kudus yang jika diurutkan menjadi urutan pertama dari urutan yang lainnya (Galatia 5:22-23) dan kasih juga memiliki sifat yang sabar, tidak mudah marah, rendah hati (1 Korintus 13:4-8). Kasih merupakan karakter yang paling berharga dan utama dalam kehidupan setiap hamba Tuhan. Hidup dalam kasih adalah hidup yang hidup dalam Roh yang memiliki kerendahan hati, mudah minta maaf dan memafkan (mengampuni) dan hidup yang tidak berpihak serta tidak mengenal sakit hati dan balas dendam. Dalam hal mengasihi, kasih dibagi menjadi 4 bagian, yaitu:

1. Kasih yang tidak bersyarat/kasih Allah (Agape)

2. Kasih antara suami istri (Eros)

3. Kasih dalam hubungan keluarga (Storge)

4. Kasih sesama teman/persaudaraan (Phileo).

Dari ke 4 bagian kasih tersebut, kasih yang sering dilakukan ialah kasih Eros, Storge dan Phileo dalam menjalin hubungan dengan sesama. Namun kasih Agape belum terdapat dalam diri hamba Tuhan, sebab kasih agape adalah kasih yang sempurna seperti Allah mengasihi manusia tanpa bersyarat, penuh pengampunan dan pengorbanan. Meskipun demikian kasih yang dituntut Tuhan dalam kehidupan hamba Tuhan ialah kasih agape.

\footnotetext{
${ }^{73}$ Ibid.,
} 
Pengertian tentang kasih menurut Waharman dalam bukunya bahwa "kasih berasal dari kata avga,ph yang memiliki pengertian kasih yang menyangkut kepeduliaan. Kepeduliaan kepada mengasihi Tuhan dan mengusahakan kebaikan bagi orang lain"74. Artinya bahwa hamba Tuhan harus memiliki karakter yang penuh kasih untuk menyatakan kepedulian kepada Tuhan dan orang lain.

Kasih ini juga didukung oleh Nygren mengatakan bahwa "agape tidak memperhitungkan kualitas baik buruk sasaran, malah menciptakan nilai baru bagi kehidupan sasaran. Karena itu, agape bersifat kreatif. Kasih ini yang diperlihatkan oleh Allah dalam kematian Yesus demi pengampunan dan keselamatan dunia»,75. Artinya kasih agape adalah kasih yang tidak melihat latar belakang yang dikasihi tetapi kasih agape mengasihi dengan tulus dan ikhlas seperti kasih Kristus dalam kehidupan manusia tanpa memandang tetapi mau berkorban bagi dunia.

Ranoh juga mengatakan "Kasih (agape) adalah prinsip utama etika Kristen. Agape yang dimaksud di sini ialah kasih agape yang bersumber dari hakikat Allah sendiri. Agape adalah kasih yang tidak mementingkan diri, tidak kenal pamrih, malahan motifnya adalah kesediaan untuk; kalau perlu berkorban demi mereka yang dikasihi" ${ }^{\text {76 }}$. Itu artinya hamba Tuhan yang memiliki karakter kasih tidak akan mementingkan dirinya sendiri tetapi orang lain juga dan bahkan rela berkorban. Ronda mengatakan:

Seorang pemimpin harus mendesain kasih terhadap orang lain. Karena kasih adalah mandat yang diberikan sebagai murid Kristus, yaitu mengasihi orang lain sebagaimana kristus telah mengasihi . Kasih itu secara ideal haruslah bersifat spontan dan tanpa syarat (unconditional). Suatu studi dibuktikan bahwa bentuk kasih itu harus didesain dan perlu kerja keras untuk mewujudkannya. Hal ini doalah yang menjadi kunci untuk dapat mengasihi",77.

Kasih itu seperti kasih terhadap saudara sendiri adalah dasar dan kegenapan kehidupan Kristen, kasih itu juga menjadi dasar segala hubungan sosial. Jikalau seseorang mempunyai kasih sedemikian, tentu ia akan berusaha supaya ia tidak menjadi beban bagi orang lain" ${ }^{, 78}$. Msweli dan Crider mengatakan bahwa:

Selain seorang hamba Tuhan mengasihi diri sendiri, hamba Tuhan juga harus mengasihi orang lain dengan kasih yang tidak dibatasi oleh ruang dan waktu tanpa memiliki kejenuhan karena melihat Karakter orang lain (1 Korintus 13:1-8). Kasih tidak sekedar kasih yang dimiliki oleh seorang

\footnotetext{
${ }^{74}$ Waharman, Kerohanian dan Karakter Pemimpin Kristen, (Bengkulu: Media Arastamar, 2018), 68

75 A. Nygren, Agape and Eros, (London:SPCK, 1982), 210

${ }^{76}$ Ayub Ranoh, Kepemimpinan Kharismatis..., 190

${ }^{77}$ Daniel Ronda, Leadership Wisdom, (Bandung: Kalam Hidup, 2015), 166

${ }^{78}$ J. Wesley Brill, Tafsiran Surat Tesalonika, (Bandung: Yayasan kalam Hidup, 2008), 66
} 
hamba Tuhan melainkan kasih yang penuh dengan kesabaran serta mampu menerima keadaan orang lain baik itu miskin maupun kaya (1 Korintus 13:4), mengasihi orang lain seperti mengasihi seorang anak. Mengasihi seorang anak bukan berarti membiarkan mereka untuk berkarakteristik dengan kemauan sendiri melainkan mengasihi dengan cara menuntun mereka ke arah yang benar (hidup sesuai firman Tuhan) dengan penuh kelembutan. Namun semuanya itu dapat dikerjakan oleh seorang hamba Tuhan oleh karena kasih anugerah Allah dan pekerjaan Roh Kudus (Galatia 4:19; 1 Korintus 5:1-2; 1 Korintus 4:14; Roma 8:38-39) ${ }^{79}$.

Kasih adalah yang pertama dan terutama dari keempat kualitas Karakter dasar yang penting bagi seorang pemimpin rohani. Kasih adalah tanda yang dimiliki oleh semua pengikut Kristus (Yohanes 13:34-35), dan kualitas itulah yang terutama dari segalanya menurut Rasul Paulus (1 Korintus 13:13). Kasih yang tampak dalam kehidupan seorang pengikut Yesus Kristus, dinyatakan khususnya melalui ketaatan yang sempurna terhadap perintah Allah (Yohanes 14:15, 21). Selain itu, kasihlah yang muncul ketika orang lain gagal, membuat kecewa, atau berdosa kepada ${ }^{80}$. Artinya bahwa kasih sebagai penutup kesalahan dan membawa sukacita.

Kesimpulannya ialah bahwa hamba Tuhan yang hidup dalam karakter kasih adalah hamba Tuhan yang hidup dalam Roh, sebab kasih bagian dari buah Roh Kudus yang memiliki sifat sabar, tidak pemarah dan rendah hati. Kasih yang harus dimiliki oleh hamba Tuhan sebagai orang yang hidup dalam Kristus ialah kasih agape yang tidak memiliki persyaratan melainkan mengasihi dengan tulus tanpa melihat latar belakang orang yang dikasihi ataupun status orang yang akan dikasihi, mudah mengampuni, tidak pendendam, serta tidak mudah sakit hati melainkan rela berkorban.

\section{"Tidak Boleh Bertengkar"}

Seorang hamba Tuhan tidak boleh bertengkar, melainkan membawa dan hidup damai dengan orang lain, baik yang berkarakter baik maupun yang berkarakter tidak baik. Seperti yang diungkapkan oleh Blaiklock bahwa "orang yang bisa meninju atau memukul hambanya tidak layak menjadi pekerja Kristen. Ia bukan penyombong yang suka berkelahi, ia bukanlah jagoan yang angkuh atau cepat membalas dendam ${ }^{81}$. Artinya seorang hamba Tuhan haruslah orang yang hidup suka damai, penuh kerendahan hati dan menghargai orang lain serta bisa mengendalikan diri pada saat berkonflik dan senantiasa memiliki hati yang pendamai bukan pemarah.

\footnotetext{
${ }^{79}$ Seth Msweli dan Donald Crider, Gembala Sidang dan Pelayanannya, (Bandung: Kalam Hidup 2002), 59-62

${ }^{80}$ Tom Yeakley, Character Formation for Leader..., 40-41

${ }^{81}$ E.M. Blaiklock, Surat-surat Penggembalaan, (Malang: Gandum Mas, 1981), 33
} 
Budiman menegaskan bahwa "seorang pengerja Kristus harus mampu berkomunikasi dengan, tidak boleh pemarah, atau gampang marah, melainkan seorang peramah, artinya baik hati dalam pergaulan. Janganlah ia suka berbantah-bantah melainkan bersifat pendamai (bdk Roma 12:18)"82. Artinya sebagai seorang hamba Tuhan harus mampu membawa damai di manapun ia berada dan bahkan mampu mengendalikan diri sendiri disaat mengalami sebuah masalah. Sehingga dengan demikian dapat menghindari timbulnya pertengkaran.

Jadi, tidak boleh bertengkar penulis simpulkan bahwa sebagai seorang hamba Tuhan harus memiliki karakter yang suka akan kedamaian dan tidak suka membalas kejahatan dengan orang lain, sehingga dengan demikian mampu menghindari timbulnya konflik sehingga mengakibatkan pertengkaran.

\section{"Ramah Terhadap Semua Orang"}

Karakter ramah adalah karakter yang menunjukkan kualitas diri hamba Tuhan. Karakter ramah sangat diperlukan dalam membina hubungan dengan orang lain dan berdampak pada diri sendiri. Sebab orang yang memiliki karakter ramah akan banyak disukai dan akan diterima apa adanya dimanapun berada. Dalam hal ini karakter ramah terhadap semua orang didukung oleh Sosipater dalam bukunya mengatakan bahwa "syarat untuk menjadi seorang hamba adalah bukan pemarah melainkan peramah dan pendamai (1 Timotius 3:3). Karena orang pemarah bisa menjadi penghalang untuk menginsyafi kebenaran serta tidak disukai oleh orang lain. Hamba Tuhan yang pemarah akan mudah bertengkar, Paulus dalam 2 Timotius 2:24,25 menegaskan, seorang hamba Tuhan tidak boleh bertengkar, tetapi harus ramah terhadap orang lain, sabar dan lemah-lembut..."83. Artinya bahwa menjadi seorang hamba Tuhan harus memiliki karakter yang ramah yang membawa kedamaian dan menginsyafkan orang.

Karakter yang ramah mencakup tata kesopan, murah senyum dan lemah-lembut. Karakter yang ramah akan mudah menjadi pendamai, berpotensi mengatasi orang yang memiliki kebiasaan keras atau pemarah, bagai air memadamkan api. Keramahan juga mendatangkan keselarasan dan keharmonisan dalam kehidupan manusia. Keharmonisan antar pendeta dengan umat di gereja. Keharmonisan diantara orang lain anggota gereja dan keharmonisan di dalam kehidupan keluarga. Keramahan harus dilakukan terhadap orang lain, bukan hanya kepada umat tertentu saja. Misalnya terhadap orang kaya, orang popular, orang yang punya jabatan gerejawi pusat, atau orang yang sukses saja. Terhadap yang

\footnotetext{
${ }^{82}$ R. Budiman, Tafsiran Alkitab Surat-surat Pastoral I dan II Timotius dan Titus..., 27

${ }^{83}$ Karel Sosipater, Etika Pelayanan, (Jakarta: Suara Harapan Bangsa, 2009) 17
} 
miskin atau pembantu atau orang cerewet sekalipun juga mesti ramah. Ini konsekuensi dari seorang hamba Tuhan ${ }^{84}$. Itu artinya keramahan harus ditunjukkan terhadap orang lain tanpa memilih-milih baik itu orang kaya, miskin, orang terpandang maupun tidak, orang baik maupun orang jahat, sebagai hamba Tuhan harus menujukkan keramahan. Budiman juga mengatakan bahwa:

Karakter ramah terhadap orang lain harus berlaku untuk setiap orang Kristen (Filipi 4:5; Kolose 4:6), apalagi seorang hamba Tuhan pekerja gereja, hamba Tuhan (1 Timotius 3:2, 3; Titus 3:2). Dalam hal ini sengaja dipakai istilah hamba Tuhan bukan hamba Kristus atau hamba Allah. Sebab supaya pekerja gereja dapat belajar dan meneladani karakteristik hamba Tuhan (Yesaya 42:1-3;53) ${ }^{85}$.

Artinya bahwa karakter yang ramah harus dimiliki oleh setiap orang Kristen terlebih sebagai status pelayan atau hamba Tuhan harus memiliki karakter ramah yang patut dicontoh oleh orang lain

Seorang yang memiliki karakter ramah pasti sopan dan lemah-lembut yang disertai murah senyum. Berbicara tentang karakter ramah, itu mendatangkan situasi dan kondisi yang harmonis dan hangat, bahkan firman Tuhan mengatakan perkataan yang ramah itu suci (Amsal 15:26) ${ }^{86}$. Artinya bahwa jika seseorang memiliki keramahan maka karakter sopan dan lemah-lembut itu akan muncul dengan sendirinya dan membawa kedamaian. Msweli dan Crider mengatakan:

Seorang hamba Tuhan harus ramah dan bukan pemarah melainkan seperti seorang gembala domba yang baik tidak akan mencambuk dombadombanya. Seorang hamba Tuhan juga harus menujukan keramahannya melalui perkataan dan tindakan yang lemah-lembut (1 Timotius 3:3; Titus $3: 1-2 ; 1$ Tesalonika 2:7). Serta memiliki sifat yang mau menerima pendapat orang lain, mendengar serta memperhatikan jika ada orang berbicara kepadanya (kerendahan hati). Ia juga memiliki karakteristik ramah, lemah-lembut apabila ia menunjukkan kesalahan orang lain serta berusaha menolong mereka dengan penuh sukacita ${ }^{87}$.

Artinya bahwa seorang hamba Tuhan memiliki karakter ramah seperti karakter seorang hamba Tuhan yang bisa memberikan kenyamanan serta suka-menolong dengan penuh sukacita. Dari penjelasan di atas penulis dapat menyimpulkan bahwa seorang hamba Tuhan harus memiliki karakter yang ramah terhadap semua orang. Dengan demikian ia mampu mengatasi orang yang memiliki karakter keras serta dapat

\footnotetext{
${ }^{84}$ Ibid., 18

${ }^{85}$ R. Budiman, Tafsiran Alkitab Surat-surat Pastoral I dan II Timotius dan Titus..., 98-99

${ }^{86}$ Ibid., 173

${ }^{87}$ Seth Msweli dan Donald Crider, Gembala Sidang dan Pelayanannya..., 46-48
} 
memadamkan amarah. Karakter ramah ini juga mendatangkan kedamaian serta keharmonisan dengan orang lain.

\section{"Cakap Mengajar"}

Kecakapan/kepandaian merupakan sesuatu hal yang sangat penting yang harus dimiliki oleh hamba Tuhan dalam pengajaran terutama dalam menyampaikan Injil kebenaran firman Tuhan. Mengajar Alkitab adalah bagian yang penting dalam pelayanan Kristen yang sesungguhnya dan secara mendalam membicarakan isi Injil Kristus ${ }^{88}$. Artinya bahwa kepandaian dalam mengajar dan melatih Injil kepada semua orang merupakan tugas pelayanan yang sangat berharga.

Dalam hal mengajar Tuhan Yesus adalah teladan dalam Alkitab mengenai kecakapan dalam mengajar, terutama dalam mengajarkan seluruh kebenaran Injil kepada murid-murid $^{89}$. Artinya bahwa Tuhan Yesuslah teladan yang sangat baik bagi hamba Tuhan dalam mengajarkan kebenaran firman Tuhan. Nainggolan mengatakan:

Pandai mengajar merupakan tugas sebagai seorang hamba Tuhan sebagai orang yang mampu mengajarkan ajaran yang benar serta dapat membuktikan kesalahan berbagai ajaran sesat. Ungkapan ini digunakan lagi dalam 2 Timotius 2:24. Cara lain untuk mengungkapkannya ialah "mampu mengajarkan orang percaya dengan baik". Kata mengajar $\boldsymbol{\delta} \boldsymbol{\imath} \boldsymbol{\delta} \boldsymbol{\alpha} \boldsymbol{\sigma} \boldsymbol{\kappa} \boldsymbol{o}($ didasko), mengandung arti, mengabarkan, memanggil untuk mengambil keputusan menyapa orang dengan kehendak Allah bagi mereka secara utuh ${ }^{90}$.

Budiman juga mengatakan "seorang pekerja gereja harus cakap mengajar (bdk 1 Timotius 3:2), kecakapan tidak hanya bersifat intelektual, melainkan harus juga nampak dalam karakter sabar dan lemah-lembut. Dengan karakter ini orang akan mencapai hasil yang lebih baik menuntun orang yang suka melawan dari pada dengan marah dan bertengkar $^{91}$. Artinya bahwa sebagai seorang hamba Tuhan juga harus memiliki karakter yang cakap/pandai mengajar kebenaran dengan baik serta dapat membuktikan berbagai kesalahan dalam ajaran-ajaran yang bertentangan dengan Injil Kristus.

Paulus memfokuskan perhatiaannya kepada orang-orang yang memegang jabatan harus menunjukkan teladan yang baik bagi orang-orang lain. Mereka harus pandai

${ }^{88}$ Ronald W. Leigh, Melayani Dengan Efektif, (Jakarta: Gunung Mulia, 2011), 157

89 James D. Smart, The Teaching Ministry o the Church, hal. 84-85. Menurut Smart tujuan pengajaran: mengajarkan seluruh kebenaran Injil kepada murid-muridnya "supaya mereka dapat meningggalkan pengertian lama mereka yang keliru tentang Allah, diri mereka sendiri dan segala hal di dunia ini.

${ }^{90}$ John M. Nainggolan, Guru Agama Kristen Sebagai Panggilan dan Profesi, (Bandung: Bina Media, 2010), 80

${ }^{91}$ R. Budiman, Tafsiran Alkitab Surat-surat Pastoral I dan II Timotius dan Titus..., 99 
mengajar, karena peranan mereka adalah untuk meneruskan apa yang telah diajarkan kepada mereka sendiri (2 Tim. 2:2)"92. Artinya bahwa seorang hamba Tuhan harus menunjukkan karakter yang baik dalam pengajar untuk meneruskan ajaran yang telah diajarkan sebelumnya.

Pengajaran tidak hanya dilakukan melalui khotbah-khotbah di depan umum, tetapi meliputi juga peneguran secara pribadi ${ }^{93}$. Mengajar tidak hanya bagaimana seseorang lancar dan fasih berbicara tetapi juga dengan sikap hidup. Seperti yang dikatakan oleh Tulus Tu'u dalam bukunya bahwa:

Mengajar itu tidaklah hanya dilakukan denga kata-kata yang lancer dan fasih seperti seorang guru di dalam kelas. Mengajar dapat dilakukan dengan cara hidup, cara berbuat, cara berperilaku. Pengajaran yang efektif dan paling kuat serta besar pengaruhnya adalah pengajaran melalui contoh atau teladan hidup. Sebuah perubahan perilaku paling mudah dilakukan melalui contoh dan teladan hidup. ${ }^{94}$

Seorang hamba Tuhan juga diharapkan mempertanggung jawabkan ajarannya dalam mengajarkan kebenarannya kepada orang lain, sehingga dapat menghentikan ajaranajaran yang mematikan dari guru-guru palsu ${ }^{95}$. Untuk itu hamba Tuhan atau pemimpin Kristen harus mengajarkan ajaran yang sehat. Ajaran yang sehat dan sehat dan sejati adalah ajaran dan didikan yang bersumber pada ajaran Tuhan. ajaran tersebuat dapat dipelajari dalam kitab Suci. Ajaran Tuhan itu sehat dan sejati sebab, “Aku, Tuhan selalu berkata benar, selalu memberi tindakan apa yang lurus. Ya Allah, jalanMu adalah kudus! Adapun Allah jalanNya sempurna; janji Tuhan adalah murni. Hukum-hukum Tuhan itu benar, adil semuanya," (Yesaya.45:19; Mazmur 77:14). ${ }^{96}$

Jadi penulis menyimpulkan bahwa setiap hamba Tuhan harus memiliki karakter yang cakap mengajar, seperti Tuhan Yesus ketika mengajar murid-muridnya dan seorang hamba Tuhan juga tidak hanya cakap dalam mengajar tetapi juga harus bisa mempertanggung jawabkan ajarannya kepada Tuhan, dengan mengajarkan ajaran yang sehat dan benar yang berpusat dari Alkitab.

\section{"Kesabaran"}

Kesabaran merupakan karakter hamba Tuhan yang abadi danbagian dari buah Roh yang disebutkan dalam Galatia 5:22-23. Kesabaran sudah diberikan Tuhan kepada semua

\footnotetext{
${ }^{92}$ Donald Guthrie, Teologi Perjanjian Baru, (Jakarta: BPK Gunung Mulia, 1996), 92

${ }^{93}$ John Calvin, Insititutio, (Jakarta: BPK Gunung Mulia, 2000), 44

94 Tulus Tu'u, Pemimpin Kristiani Yang Berhasil...,60

95 Alexander Strauch, Kepenatuaan atau Kependetaan, (Yogyakarta: ANDI, 1999), 107

96 Tulus Tu'u, Pemimpin Kristiani Yang Berhasil 1...,55
} 
orang percaya yang bersedia membuka diri untuk dipenuhi serta dikontrol oleh Roh Kudus. Semakin mengijinkan Tuhan untuk mengarahkan hidup maka semakin menunjukkan karakteristik itu di dalam kehidupan dan pelayanan. Dapat bersabar terhadap orang lain dan diri sendiri karena Allah berdaulat serta berkuasa atas segala sesuatu yang terjadi di dunia ini. ${ }^{97}$

Kata kesabaran berasal dari kata Yunani yang menggambarkan tentang ketenangan dan ketabahan seseorang dalam menghadapi fitnah. Kata ini juga mencakup arti dapat menahan diri dari marah dan perasaan dendam terhadap perlakuan yang tidak adil dan tidak benar. Kesabaran adalah pancaran dari hati yang penuh kasih dan lemah-lembut dalam hubungannya dengan orang di sernya. Kesabaran itu memandang mereka dengan ramah dan baik. Kesabaran itu menilai kesalahan orang lain dengan rasa iba, ramah dan pengertian tanpa mengkritik dengan tidak adil. Kesabaran termasuk ketekunan kemampuan untuk menanggung keletihan, tekanan, dan aniaya pada waktu mengerjakan pekerjaan Tuhan ${ }^{98}$. Artinya bahwa menggambarkan ketenangan seseorang dalam menghadapi sesuatu hal dan kesabaran itu juga merupakan pancaran dari hati yang penuh kasih. Caram juga mengatakan

Sabar kadang-kadang diartikan sebagai kesabaran yang artinya watak yang tenang dan bisa menahan diri, sabar adalah keadaan hati yang tetap sabar walau terus menerus dipancing atau digodai. Kesabaran tidak bisa diperoleh begitu saja dan kesabaran dapat dipersamakan dengan kemenyan"99.

Artinya bahwa kesabaran merupakan watak yang tenang serta bisa mengendalikan diri dalam berbagai hal. Hamba Tuhan yang memiliki kesabaran bisa disamakan dengan kemenyan yang digunakan untuk wewangian. Untuk mendapatkan kesabaran dan menjadi orang yang sabar tidaklah mudah melainkan perlu pengorbanan dan kegigihan yang luar biasa $^{100}$. Artinya tidak gampang seseorang memiliki karakter yang sabar, namun demikian tetap harus memiliki karakter seperti itu.

Hamba Tuhan itu membutuhkan sikap sabar dalam tugasnya. Karena ada banyak hal yang dapat menekan dan menghimpitnya dalam tugas kepemimpinannya. Lebih-lebih dalam melayani kesabaran yang sangat ekstra sangat dibutuhkan. Jikalau hamba Tuhan melatih dan mengembangkan kesabaran dan doanya, sungguh luar biasa pengaruh dan

\footnotetext{
${ }^{97}$ Tom Yeakley, 10 Karakter Yang Harus Dimiliki Pemimpin Kerajaan Allah, (Bandung:Yayasan Kalam Hidup,2013),211

${ }_{98}$ Billy Graham, Roh Kudus, (Bandung: Lembaga Literatur Baptis, 1985), 323

${ }^{99}$ Paul G. Caram, Kekristenan Sejati, (Jakarta: Voice Of Hope, 2004), 116

${ }^{100}$ Piero Ferrucci, Bagaimana Menjadi Orang Baik, (Jakarta: Gunung Mulia, 2009), 127-130
} 
hasilnya bagi pelayanannya. Hamba Tuhan akan penuh akal budi dan pengertian. Perbantahan dan kesalahan besar dapat dihindari dan mampu bertahan dalam kesesakan. ${ }^{101}$

Tom Yeakley mengatakan "Pemimpin yang kurang sabar mudah meluapkan amarahnya" $" 102$. Octavianus juga dalam bukunya mengatakan "pemimpin yang tidak sabar dan tidak sanggup menguasai diri pasti banyak menemui kesulitan yang berbahaya dalam kepemimpinannya. Untuk mencapai kesabaran itu membutuhkan proses pembentukan Tuhan yang tidak singkat". ${ }^{103}$ Seorang hamba Tuhan harus belajar kepada Rasul Paulus yang menunjukkan kesabaran sebagai salah satu bagian bukti dari pelayanannya (2 Korintus 6:6). Seseorang yang tidak sabar tidak seharusnya memiliki kuasa. Menurut Rasul Paulus kesabaran itu penting bagi setiap orang kristen. Kesabaran termasuk dalam buah Roh sebab sesungguhnya kesabaran hanya dihasilkan oleh Kristus yang ada di dalam diri ${ }^{104}$. Waharman juga mengatakan

Kesabaran Rasul Paulus dalam menghadapi penderitaan adalah luar biasa. Sesudah Kristus, maka hamba Tuhan yang ditonjolkan adalah ikut Tuhan adalah sukses. Penderitaan memberi pelajaran yang banyak bagi imam Kristen. Penderitaan menyapih manusia dari dunia ini, sehingga manusia menaruh sepenuhnya kepada Allah" ${ }^{105}$.

Artinya kesabaran adalah hal yang harus dimiliki oleh setiap hamba Tuhan dalam pelayanan dan bahkan dalam menghadapi penderitaan dengan terus-menerus.

Dari penjelasan di atas penulis dapat menyimpulkan bahwa, seorang hamba Tuhan harus memiliki karakter sabar dalam segala hal dalam pelayanan karena kesabaran akan membuat tenang dalam menghadapi segala sesuatu yang terjadi dalam pelayanan. Kesabaran tidak dapat dihasilkan oleh diri sendiri tetapi itu merupakan pemberian Tuhan melalui Roh Kudus. Kesabaran juga merupakan suatu pendidikan yang tidak ada batas.

\section{"Lemah Lembut"}

Lemah-lembut merupakan karakter yang dikehendaki dalam diri hamba Tuhan (Efesus 4:2). Lemah-lembut merupakan sikap kerendahan hati di hadapan Tuhan yang bisa menerima rasa sakit hati yang diakibatkan oleh orang lain. Kelemah-lembutan ini juga diajarkan Paulus kepada jemaat di Korintus (Kisah Para Rasul 18:1-11), kelemahlembutan menunjukkan kebaikan yang terpancar dari hati (Filipi 4:5). Karakteristik lemahlembut in juga didukung oleh Gulo mengatakan "Kelemah-lembutan adalah salah satu

\footnotetext{
${ }^{101}$ Tulus Tu'u, Pemimpin Kristiani Yang Berhasil 2...,33

${ }^{102}$ Tom Yeakley, 10 Karakter Yang harus dimiliki Pemimpin Kerajaan Allah...,209

${ }^{103}$ P.Octavianus, Manajemen dan Kepemimpinan Menurut Wahyu Allah, (Batu:YPPII, 1997),187.

${ }^{104}$ M. Drescher, Melakukan Buah Roh, (Jakarta: Gunung Mulia, 2009), 139

${ }^{105}$ Waharman, Kerohanian dan Karakter Pemimpin Kristen..., 64-65
} 
karakteristik yang harus dimiliki oleh orang Kristen. Kelemah-lembutan ini adalah salah satu cara mewujudkan damai sejahtera di tengah dunia yang multicultural ${ }^{106}$. Orang yang lemah lembut adalah orang yang penuh pertimbangan untuk orang lain dan kemauan untuk membebaskan orang lain" ${ }^{107}$. Artinya bahwa orang yang memiliki karakteristik kelemah-lembutan adalah orang yang penuh dengan belas kasihan yang memiliki banyak pertimbangan serta mampu mengendalikan diri sendiri.

Dunn juga mengatakan bahwa "kelemah-lembutan adalah kekuatan yang memungkinkan bisa bertemu dengan orang yang sedang konflik dengan orang lain"108. Ini menujukan bahwa kekuatan yang dimaksud adalah kemampuan yang dimiliki oleh seseorang untuk memberikan solusi dalam sebuah konflik yang dihadapi dengan penuh pertimbangan yang lemah-lembut.

Matthew dalam bukunya juga mengatakan "betapa tidak pantasnya orang-orang yang tidak dapat menguasai dirinya sendiri, atau menguasai nafsu mereka yang bergejolak dan tidak tertib, untuk memimpin suatu jemaat, seorang pelayan haruslah lemah lembut, ramah dan sabar terhadap semua orang." 109 Artinya bahwa untuk dapat memimpin jemaat, dibutuhkan kelemah lembutan. Kelemah lembutan bukan sifat lembut, sopan, dan penuh kesabaran yang tampak dari luar, melainkan sifat lemah lembut dan penuh timbang rasa di dalam diri seseorang; bukan cara seseorang berperilaku, melainkan kondisi fikiran dan hatinya. Kelemah-lembutan berkaitan erat dengan 'kerendahan hati'. Sebaliknya, keangkuhan membuat seseorang suka meninggikan diri dan bisa jadi sering memperlakukan orang lain secara kasar dan tidak berperasaan ${ }^{110}$.

Karakteristik yang penuh kelemah-lembutan inilah yang seharusnya dimiliki oleh seorang hamba Tuhan. Karakteristik yang lemah-lembut ini dapat menjadi alat dan kekuatan dalam pelayanan serta mampu memberikan kedamaian dan kesejahteraan terhadap orang lain dan mampu menangani setiap masalah. Orang yang memiliki kelemahlembutan adalah orang yang tidak mengenal sakit hati ataupun dendam melainkan memiliki kerendahan hati, menguasai diri dan mau menerima diri apa adanya beserta nasihat yang diberikan.

\footnotetext{
${ }^{106}$ Manase Gulo, Pemimpin Yang Alkitabiah, (Bengkulu: Permata Raflesia, 2018), 81

${ }^{107}$ Peter T. O’Brien, Word Biblical Commentary Volume 44 Collosians, Philemon, (Texas: Waco, 1982), 199

${ }^{108}$ James D. G. Dunn, The Epistles To The Colossians and to Philemon A Commentary on the Greek Text, (Grand Rapids, Michigan, 1996), 228

109 Matthew Henry,Tapsiran Galatia, Efesus, Filipi, Kolose, $1 \& 2$ Tesalonika,1\&2 Timotius,Titus, Filemon...,744

110 Ibid
} 


\begin{abstract}
APLIKASI
Dari paparan yang sudah ada maka penulis merangkum bahwa surat 2 Timotius ditulis sendiri oleh Rasulu Paulus yang langsung ditujukkan kepada anak rohaninya yaitu Timotius yang sering disebut surat Pastoral (penggembalaan). Surat ini ditulis oleh Paulus pada tahun 67 di kota Roma pada saat berada dalam penjara saat orang Kristen mengalami penganiayaan. Adapun tujuan mengapa Rasul Paulus menulis surat kepada Timotius karena pada saat itu ada goncangan yang hebat yang dialami oleh Timotius baik dari dalam dirinya maupun dalam pelayanannya dimana ada pengajaran injil selain Injil Kristus.

Dari hal tersebut maka Rasul Paulus khawatir atas iman kepercayaan Timotius sebab Timotius masih muda dan mudah terpengaruh akan kesenangan-kesenangan dunia yang menggoda seperti nafsu yang dimiliki oleh orang muda yang sulit untuk dikendalikan. Meskipun Timotius hidup kudus di hadapan Tuhan tetapi Timotius juga harus waspada akan nafsu duniawi. Maka dengan itu Rasul Paulus menasihati Timotius untuk menghindari nafsu duniawi maka Timotius harus mengejar keadilan, kasih dan kesetiaan serta Timotius juga harus memiliki karakteristik yang ramah, tidak cepat emosi dan penuh dengan kelemah-lembutan.

Karakteristik merupakan hasil dari apa yang telah didengar dan telah dirasakan baik secara fisik maupun kejiwaan dalam bentuk tindakan. Karakteristik juga merupakan ciri khas yang dimiliki oleh seseorang. Jadi karakteristik hamba Tuhan adalah tindakan yang dilaksanakan oleh pelayan Tuhan yang mau melayani, mau melakukan firman Tuhan dan hidup sesuai firman Tuhan tanpa tergantung situasi dan kondisi. Namun tidak terlalu sulit jika melihat karakteristik yang dimiliki oleh seseorang bila terlibat dalam sebuah interaksi dengan orang lain dalam intesitas dan waktu yang cukup lama.
\end{abstract}

\title{
Karakteristik Hamba Tuhan Menjauhi Nafsu Orang Muda
}

Hamba Tuhan yang memiliki karakteristik menjauhi nafsu orang muda harus bisa mengendalikan diri dari berbagai macam nafsu seperti ketidak sabaran, penonjolan diri, menyukai pertengkaran dan menyukai sesuatu yang baru (tidak hanya menjurus pada nafsu kelamin). Hamba Tuhan yang memiliki karakteristik menjauhi nafsu orang muda harus bisa menarik diri dari perkumpulan orang jahat dan membangun hubungan yang intim dengan Tuhan supaya tidak memiliki fikiran yang jahat. Hamba Tuhan harus memiliki karakteristik yang menjaga dan menjauhkan diri dari berbagai nafsu duniawi dan harus mengejar keadilan, kesetiaan dan kasih.

\section{Karakteristik Hamba Tuhan Mengejar Keadilan}


Seorang hamba Tuhan harus memiliki karakteristik yang suka mengejar keadilan yang berpegang teguh pada kebenaran Allah dan supaya memimpin dengan benar dan tidak sewenang-wenang dalam mengambil sebuah keputusan. Dan untuk menjadi seorang hamba Tuhan yang adil dan mengarahkan seluruh hidupnya kepada Tuhan sebagai sumber keadilan.

\section{Karakteristik Hamba Tuhan Yang Mengejar Kesetiaan}

Seorang hamba Tuhan harus memiliki karakteristik yang mengejar kesetiaan dalam mempertahankan imannya kepada Tuhan apapun yang terjadi. Hamba Tuhan yang memilik karakteristik kesetiaan harus mampu menunjukkan iman yang kuat, yang berbobot, bukan iman yang kosong dan mati tetapi bisa diteladani. Seorang hamba Tuhan juga harus memiliki karakter yang setia dalam pelayanan, setia memegang ajaran, pesan dan amanat janji Tuhan.

\section{Karakteristik Hamba Tuhan Mengejar Kasih}

Sebagai hamba Tuhan harus memiliki karakteristik hamba Tuhan yang mengejar kasih. Hamba Tuhan harus mampu mendesai kasih dan perlu kerja keras untuk mewujudkannya. Kasih yang diwujudkan merupakan kasih yang spontan tanpa syarat (unconditional). Dalam hal ini kasih yang harus dimiliki oleh hamba Tuhan ialah kasih yang tidak mementingkan diri sendiri tetapi orang lain, tidak kenal pamrih, tetapi kasih yang dari Allah yaitu kasih yang rela berkorban. Hamba Tuhan harus mengejar kasih karena kasih merupakan sebuah mandat dari Kristus bagi hamba-hamba Tuhan. Karena kasih adalah hal yang pertama dan terutama dari keempat kualitas dasar yang penting bagi hamba-hamba Tuhan (1 Korintus 13:13). Kasih yang harus dimiliki oleh hamba Tuhan ialah kasih seperti yang dimiliki oleh Allah kepada manusia yaitu kasih agape yang di dalamnya ada pengampunan. Dan sebagai hamba Tuhan melayani tanpa kasih adalah siasia.

\section{Karakteristik Hamba Tuhan Tidak Boleh Bertengkar}

Menjadi seorang hamba Tuhan bukanlah seorang hamba penyombong, jagoan yang angkuh yang cepat membalas dendam dan bukan pula yang suka bertengkar melainkan seorang yang mampu membawa damai di manapun berada dan mampu mengendalikan diri sendiri disaat mengalami sebuah masalah. Sebab orang yang suka bertengkar tidak dapat menghindari konflik yang mengakibatkan pertengkaran.

\section{Karakteristik Hamba Tuhan Ramah Terhadap Semua Orang}


Setiap orang yang mengabdikan diri sebagai hamba Tuhan harus memiliki karakter yang ramah. Ramah merupakan sifat yang harus dimiliki oleh setiap orang dan ditunjukkan untuk semua orang tanpa terkecuali. Keramahan dapat menciptakan keharmonisan dalam membina sebuah relationship antara sesama. Jadi syarat untuk menjadi seorang hamba Tuhan bukanlah pemarah melainkan peramah (1 Timotius 3:3) yang mampu membawa damai dan bisa menginsyafkan orang. Karakter ramah terhadap orang lain harus berlaku untuk setiap orang kristen, terlebih sebagai hamba Tuhan (Filipi 4:5; Kolose 4:6; Titus $3: 2)$.

\section{Karakteristik Hamba Tuhan Cakap Mengajar}

Karakteristik hamba Tuhan yang cakap mengajar sangat diperlukan oleh hamba Tuhan. Sebab kecakapan adalah suatu hal yang sangat penting yang harus dimiliki oleh hamba Tuhan dalam mengajar terutama dalam menyampaikan Firman Tuhan. Mengajar tentang Alkitab merupakan hal yang terpenting dalam pelayanan Kristen yang sesungguhnya karena di dalamnya berbicara tentang Injil Kristus. Dan bukan pula cakap dalam berkhotbah melainkan juga dapat menegur secara pribadi. Kecakapan yang dimiliki oleh hamba Tuhan tidak hanya bersifat intelektual melainkan harus nampak dalam karakter sabar dan lemah-lembut. Sebagai hamba Tuhan yang cakap mengajar tidak lepas dari berbagai tantangan, ancaman dan godaan. Oleh sebab itu supaya setiap ajaran yang diajarkan kembali tidak menjadi sia-sia maka diperlukan yang namanya kesabaran dalam segala kesukaran.

\section{Karakteristik Hamba Tuhan Sabar}

Dalam kehidupan hamba Tuhan kesabaran sangat dibutuhkan sebab ada banyak godaan, cobaan, tantangan dan penderitaan, tekanan yang dihadapi. Dengan demikian kesabaran harus dimiliki oleh hamba Tuhan agar tidak cepat marah, putus asa dan terburu oleh nafsu. Kesabaran adalah salah satu dari Sembilan buah Roh Kudus (Galatia 5:22-23) di mana kesabaran diberikan kepada orang yang membuka hati untuk dipenuhi oleh Roh Kudus. Namun untuk menjadi orang yang memiliki karakter sabar tidak mudah melainkan perlu pengorbanan dan kegigihan yang luar biasa.

\section{Karakteristik Hamba Tuhan Lemah-lembut}

Kelemah-lembutan adalah salah satu karakteristik yang harus dimiliki oleh orang Kristen. Orang yang lemah-lembut adalah orang yang penuh pertimbangan untuk orang lain dan kemauan untuk membebaskan orang lain yang penuh dengan belas kasihan serta mampu mengendalikan diri sendiri. Lemah-lembut tidak hanya tertuju pada sifat yang 
sopan yang tampak di luar diri melainkan lemah-lembut yang mencakup kerendahan hati yang terpancar dari dalam hati. Karakteristik hamba Tuhan yang lemah-lembut harus dimiliki oleh hamba Tuhan guna untuk menjadi alat dan kekuatan dalam pelayanan sehingga dapat memberikan kedamaian dan kesejahteraan orang lain dan mampu memberikan sebuah solusi dalam setiap masalah.

\section{PENUTUP}

Berdasarkan paparan di atas maka penulis merangkum bahwa "Karakteristik hamba Tuhan" berdasarkan 2 Timotius 2:22-25 adalah karakter yang mengarah pada watak seseorang, ciri khas yang dimiliki oleh seseorang yang tidak dimiliki oleh orang lain. Namun yang lebih penting dari karakter ialah tindakan dan perbuatan dari pada perkataan. Seperti yang terdapat dalam Alkitab bahwa kehendak Allah harus dinyatakan me Im... tingkah laku terhadap orang lain dan untuk memiliki karakter hamba Tuhan tidak bergantung pada situasi dan kondisi.

Rasul Paulus menulis suratnya kepada Timotius anak, supaya Timotius dalam menghadapi berbagai tantangan dan ajaran sesat (Himeneus dan Aleksander) yang tidak percaya akan kebangkitan serta memiliki faham Gnostik. Paulus menasihati Timotius melalui suratnya guna untuk menguatkan iman Timotius sebagai hamba Tuhan, supaya tidak jatuh ke dalam dosa kenikmatan seks di mana di kota Efesus sangat terkenal dengan namnya Dewi Arthemis dan penduduk yang suka melakukan seks dan supaya tetap hidup dalam Tuhan dan melakukan Firman Tuhan.

Dalam 2 Timotius 2:22-25 Rasul Paulus memaparkan kepada Timotius bahwa Timotius dalam berpegang teguh dalam kebenaran Tuhan dan tetap memiliki hidup kudus, maka Timotius harus memiliki karakteristik seorang hamba Tuhan sebagai berikut: Karakteristik hamba Tuhan menjauhi nafsu orang muda, karakteristik mengejar keadilan, karakteristik hamba tuhan dalam mengejar kesetiaan, karakteristik hamba tuhan mengejar kasih, karakteristik hamba tuhan tidak boleh bertengkar, karakteristik hamba tuhan ramah terhadap orang lain, karakteristik hamba tuhan cakap mengajar, karakteristik hamba tuhan sabar dan karakteristik hamba tuhan yang lemah-lembut. 


\section{DAFTAR PUSTAKA}

Ali, Lukman

1991 Kamus Besar Bahasa Indonesia, Jakarta: Balai Pustaka

Alkitab Penuntun

Arichea, Daniel C. dan Hatton, Howard A.

2014 Surat-surat Paulus Kepada Timotius dan Kepada Titus, Jakarta: LAI

Arikunto, Suharsimi

2002 Prosedur Penelitian Suatu Pendekatan Praktek, Jakarta:

Bineka Cipta

Barclay, William

$2001 \quad$ Pemahaman Alkitab Setiap Hari, Jakarta: Gunung Mulia

BibleWorks 7

Blaiklock, E.M

1981 Surat-surat Penggembalaan, Malang: Gandum Mas

Blankenbaker, Frances 2007 Inti Alkitab Untuk Para Pemula, Jakarta: Gunung Mulia

Borrong, Robert P. 2006

Budiman, R.

2011 Surat-surat Pastoral dan 2 Timotius Dan Titus, Jakarta:

Gunung Mulia

Brill, J. Wesley 2011 Tafsiran Surat Tesalonika, Bandung: Yayasan Kalam Hidup

Browning, W.R.F. $2011 \quad$ Kamus Alkitab, Jakarta: Gunung Mulia

Calvin, John $2000 \quad$ Insititutio, Jakarta: BPK Gunung Mulia

Caram, Paul G. 2004

Chapman, Adina 2014 Pengantar Parjanjian Baru, Bandung: Kalam Hidup

Chauke E. dan Beckelhymer, B.

Cressey, M.H.

Penyelidikan Perjanjian Baru-Jilid 3, Bandung: Kalam Hidup 2006 Timotius Dan Titus Dan Donald Guthrie C. Stamps, Alkitab

Daun, Paulus

2010

Depiyanti, Ucik

2012

Douglas, J.D

1995

Drane, Jhon

Penuntun Hidup Berkelimpahan, Malang: Gandum Mas

Pengantar Ke Dalam Perjanjian Baru 2, Manado: Yayasan Daun Family

Skripsi Perspektif Yakobus Tentang Pencobaan Berdasarkan Yakobus 1:12-15 dan Kontribusinya Bagi Mahasiswa Sekolah Tinggi Teologi Arastamar Bengkulu (STTAB), Bengkulu

Ensiklopedi Alkitab Masa Kini, Jakarta: Yayasan Bina Kasih

Memahami Perjanjian Baru, Jakarta: Gunung Mulia 
Drescher, $\mathrm{M}$.

2009

Dunn, James D. G.

1996

Duyverman, M.E.

2011

E, Arnold

1969 Beacon Bible Commentary, USA: Beacon Hill Press

Echlos, John M.

1982 Kamus Inggris Indonesia, Jakarta: Gramedia Pustaka Utama

Edewin, Mustafa dan Hardius

2008

Eerdmans, William .

1999

Erick, Sudharma

2003

Ferrucci, Piero

2009

Gibbs, Eddie

2010

Graham, Billy 1985

Gulo, Manase 2018

Guthrie, Donald 1996

Hadi, Satrisno

1984

Hakh, Samuel Benyamin

Proses Penelitian Kuantitatif, Jakarta: Lembaga Penerbit FEUI

Pembimbing Ke Dalam Perjanjian Baru, Jakarta: Gunung Mulia

Exegetical Dictionary of the new testament, America: Publishing Company

Menekuni Jalan Salib, Bandung: Literatur Perkantas Jawa Barat

Bagaimana Menjadi Orang Baik, Jakarta: Gunung Mulia

Kepemimpinan Gereja Masa Mendatang, Jakarta: Gunung Mulia

Roh Kudus, Bandung: Lembaga Literatur Baptis

Pemimpin Yang Alkitabiah, Bengkulu: Permata Raflesia

Teologi Perjanjian Baru, Jakarta: BPK Gunung Mulia

Statistik II, Yogyakarta: Yayasan Fakultas Sosiologi Universitas Gajah Mada

2010 Perjanjian Baru, Bandung: Bina Media Informasi

Halim, Andreas

Hastings, J.

1996

Henry, Matthew

2015

Houston, James 2001

Husaini,
Kamus Lengkap 50 Miliyar, Surabaya: Sulita Jaya

"II Timotius" dalam J.D Donal Guthrie (Ed), Ensiklopedia Alkitab Masa Kini Jilid 2 Jakarta: Yayasan Komunikasi Bina Kasih

Surat Galatia, Efesus, Filipi, Kolose, Idan 2 Tesalonika, 1 dan 2 Timotius, Titus, Filemon, Surabaya: Momentum

Handbook To The Bible, IKAPI 
$1996 \quad$ Metode Penelitian Social, Jakarta: Bumi Aksara

Jhonson, Lewis 2001

"1 Korintus" dalam Charles Pfeiffer dan Everett F. Horrison

Kee, Howard Clark 1961 (Ed), The Wiclife Bible Comentary, Malang: Gandum Mas

Kountor, Roni 2007

\author{
Alkitab Edisi Study, Jakarta: LAI
}

Metode Penelitian, Jakarta: PPM Manajemen

Klemens, I 1919

Martin, M. Andre 2002

Leigh, Ronald W 2011

Marantika, Chris

The Apostolic Fathers, London: William Heinemann

Kamus Besar Bahasa Indonesia, Surabaya: Karina

Melayani Dengan Efektif, Jakarta: Gunung Mulia

Martin, M. Andre 2002

Kepercayaan dan Kehidupan Orang Kristen

Moulton, Harold K. 1978

Kamus Besar Bahasa Indonesia, Surabaya: Karina

The Analitical Greek Lexicon Revised, Zondervan Publishing House

Msweli, Seth dan Crider, Donald

2002 Gembala Sidang dan Pelayanannya, Bandung: Kalam Hidup

Nainggolan, John M.

2010

Guru Agama Kristen Sebagai Panggilan dan Profesi, Bandung: Bina Media

Naution, Mustafa Erwin dan Usman Hardius,

2006

Nazir, Muhamad 2003

Ningrat, Kuncoro 1997

Nygren, A.

1982

O'Brien, Peter T 1982

Octavianus, $\mathrm{P}$ 1997

Paizal, Sapinah 1982

Palmer 2002

Peter T. O’Brien,
Proses Penelitian Kuantitatif, Jakarta: Fakultas Ekonomi Universitas Indonesia

Metode Penelitian, Jakarta: Gratiam Indonesia

Methodologi Penelitian, Jakarta: Gramedia

Agape and Eros, London: SPCK

Word Biblical Commentary Volume 44 Collosians, Philemon, Texas: Waco

Manajemen dan kepemimpinan Menurut Wahyu Allah, Batu:YPPII

Metode Penelitian Pendidikan, Surabaya: Usaha Nasional

"Kasih” dalam JD. Douglas (Ed), Ensiklopedia Alkitab Masa Kini Jilid I Jakarta: YKBK 
1982

Word Biblical Commentary Volume 44 Collosians, Philemon, Texas: Waco

Podo, Siswo Prayitno Hadi

2012 Kamus Besar Bahasa Indonesia Edisi Baru, Jakarta: PT Media Pustaka Phoenix,

Pfeiffer, Charles F. dan Harrison, Everett F

2013

The Wycliffe Bible Commentari Volume 3, Malang: Gandum

Mas

Ranoh, Ayub

2011

Riggs, Ralph M.

1987 Gembala Sidang Yang Berhasil, Malang: Gandum Mas

Robinson, John Arthur Thomas

$1976 \quad$ Redating The New Testament, Westminster Press

Ronda, Daniel

2015 Leadership Wisdom, Bandung: Kalam Hidup

Sabda

Siahaan, Edi D. H. Tambunan, Manik R. Manginar 2006

Sosipater, Karel

2009

2010

Subandrijo, Bambang

2010

Sugono, Dendy

2011

Supriadinata,

2009

Susanto, Hasan

2006

Susilo, Willy

2013

Smart, James D

Stamps, Donald C

Stibbs, A.M.

1995

Strauch, Alexander

1999
Etika Sekolah Menengah Teologi Kristen, Medan: Mitra Medan

Etika Pelayanan, Jakarta: Suara Harapan Bangsa

Etika Pelayanan, Jakarta:Suara Harapan Bangsa

Menyingkap Pesan-Pesan Perjanjian Baru, Bandung: Bina Media Informasi

Kamus Besar Bahasa Indonesia Pusat Bahasa, Jakarta: PT gramedia Pustaka Utama

Skripsi Doktrin Pemilihan dan Predestinasi Allah dalam Karya Keselamatan Dalam Efesus 1:3-14 dan Implikasinya Bagi Pelayanan Misi dan Penginjilan Mahasiswa/i Sekolah Tinggi Teologi Arastamar Bengkulu (STTAB), Bengkulu

Perjanjian Baru Interlinear Yunani-Indonesia dan Konkordansi Alkitab Pb (PBIK) Jilid II, Jakarta: LaI

Membangun Karakter Unggul, Yogyakarta: Penerbit Andi

The Teaching Ministry o the Church

Alkitab Penuntun Hidup Berkelimpahan

Tafsiran Alkitab Masa Kini 3, Jakarta: Komunikasi

Bina Kasih

Kepenatuaan atau Kependetaan, Yogyakarta: ANDI 
Strong's Data For "Faith" 4102 dalam Bible Works 7

Tambunan, Edi D. H, Siahaan, R. dan Manik, Manginar

2006 Etika Sekolah Menengah Teologi Kristen, Medan: Mitra Medan

Tenney, Merrill C.

1997 Survei Perjanjian Baru, Malang: Gandum Mas

Tim Penyusun

2012

at. al Katalog 2009-2014 Sekolah Tinggi Teologi Arastamar Bengkulu, Bengkulu

2017-2030 Rencana Induk Pengembangan (STTAB), Bengkulu

Tu'u, Tulus

2010 Pemimpin Kristiani Yang Berhasil, Bandung:Bina Media Informasi

Usman, Syafrein Effendi dan Ishak, Norain

1992 Nafsu dan Perkahwinan, Kuala Lumpur: Kintan,

Waharman,

2018 Kerohanian dan Karakter Pemimpin Kristen, Bengkulu:

Media Arastamar

Wiersbe, Warren W.

1972

Nyata Di Dalam Kristus, Bandung: Kalam Hidup

Yeakley, Tom

2013

10 Karakter Yang Harus Dimiliki Pemimpin Kerajaan Allah, Bandung:Yayasan Kalam Hidup 